\title{
Construir con ladrillo en la periferia de al-Ándalus hacia el año 1000. La actividad fronteriza califal y la "mampostería encintada cajeada"*
}

\author{
Brick construction in the periphery of al-Ándalus to AD 1000. \\ Caliphal border activity and the "stone lacing brickwork"
}

\author{
Enrique Daza Pardo ${ }^{1}$ \\ Universidad Autónoma de Madrid
}

\begin{abstract}
RESUMEN
El presente trabajo pretende acercarse al uso del ladrillo en construcción en el centro peninsular, a ambos lados del Sistema Central, a través del estudio de varios edificios construidos con una mampostería mixta particular denominada "aparejo encintado cajeado". Tras el análisis de cada uno de los edificios reconocidos, este estudio pone de manifiesto que se trata de un grupo constructivo ciertamente homogéneo y cohesionado, orientado a la construcción de edificios de diversa tipología, no solo fortificaciones, do nde lo s ma teriales em pleados y las técnicas desarrolladas son similares entre sí en composición y métrica, cercanos a las formas toledanas altomedievales. Todo esto lleva a plantear que ha sido posibilitado por una acción foránea, pudiendo estar relacionado con un efímero proceso colonizador cordobés efectuado a finales del siglo X.
\end{abstract}

Palabras clave: arquitectura islámica; fortificaciones; mezquitas; ladrillo; Almanzor; Segovia; Madrid; Guadalajara; Toledo.

\begin{abstract}
This study attempts to identify the main characteristics of the use of brick construction in the peninsular center, in both sides of the Sistema Central, through the study of several buildings erected with a particular mixed masonry called "stone lacing brickwork". After analyzing each of the recognized buildings, this study reveals that it is certainly a homogeneous and cohesive assembly group; focused on the conformation of buildings of various types, not only fortifications, where the materials which were implemented and the techniques developed are similar to each other in composition and measuring, near the early medieval Toledo's type. All this leads to posit that has been made possible by a foreign action which it may be related to an ephemeral cordovan colonization process carried out at the end of the tenth century.
\end{abstract}

Key words: Islamic architecture; fortifications; mosques; brick; Almanzor; Segovia; Madrid; Guadalajara; Toledo.

Recibido: 04-04-2018. Aceptado: 17-05-2018. Publicado online: 21-12-2018

Cómo citar este artículo / Citation

Daza Pardo, E. 2018: "Construir con ladrillo en la periferia de al-Ándalus hacia el año 1000. La actividad fronteriza califal y la 'mampostería encintada cajeada'", Arqueología de la Arquitectura, 15: e077. https://doi.org/10.3989/arq.arqt.2018.021

Copyright: (c) 2018 CSIC. Este es un artículo de acceso abierto distribuido bajo los términos de la licencia de uso y distribución Creative Commons Reconocimiento 4.0 Internacional (CC BY 4.0).

\footnotetext{
* El presente trabajo se enmarca en el proyecto de investigación I+D+i Confrontatio: Violencia religiosa en la Edad Media peninsular: guerra, discurso apologético y relato historiográfico (ss. $X-X V$ ) financiado por la Agencia Estatal de Investigación del Ministerio de Economía y Competitividad del Gobierno de España (HAR2016-74968-P) y dirigido por D. Carlos de Ayala Martínez y D. Santiago Palacios Ontalva.

1 enrique.daza@uam.es / ORCID iD: https://orcid.org/0000-0001-9370-7635
} 


\section{INTRODUCCIÓN ${ }^{2}$}

"Cuando conquisté las tierras de los cristianos y sus fortalezas las repoblé [y avituallé] con los medios de subsistencia de cada lugar y las sujeté con ellas hasta que resultaron favorables completamente".

Con estas palabras recogidas por Ibn al-Kardabūs en su Historia de al-Andalus (1993: 86), Almanzor se enorgullece de haber colonizado y fortificado algunas de las tierras que conquistó a los cristianos, empleando los medios que le ofrecía cada lugar. En opinión de F. Maíllo Salgado (1984: 165-167), es prueba de que estas repoblaciones del territorio conquistado se efectuaron y fueron efectivas a través de un sistema de colonización de tipo militar, pero ¿es posible rastrear materialmente este hecho?, ¿existen evidencias constructivas que avalen esta aseveración?

El presente trabajo pretende acercarse a la revisión de algunas manifestaciones arquitectónicas ya conocidas, ejecutadas empleando mampostería encintada cajeada, ya que se han querido asociar a la iniciativa andalusí, fundamentalmente en el caso del castillo de Ayllón (Zamora 1993: 213-223) o en el de la Torre de San Andrés de Sepúlveda (Conte y Fernández 1993: 196-198; Martín, Tardío y Zamora 1990: 83-85; Zamora 2011: 176-188), donde se ha propuesto ajustar la cronología de estos edificios a la época de Almanzor, más concretamente, posteriores al asedio de Sepúlveda del año 984. Se trataba de una hipótesis difícil de contrastar y de fundamentar, pero orientada hacia un momento y unas circunstancias históricas que deben ser mejor explicadas y puestas en contexto, a fin de confirmar esa propuesta o de establecer otras nuevas, con el consiguiente ajuste cronológico y cultural que esto conllevaría. A través de la revisión y estudio de los edificios en los que se ha documentado este aparejo, todos ellos localizados tanto en el este de la provincia de Segovia como en el norte de Guadalajara y Madrid, se pretende dilucidar la razón de ser de esta técnica constructiva, motivar su presencia en ambas laderas del Sistema Central y su aparente carácter efímero, así como la ausencia, por el momento, de unos paralelos claros fuera de esta zona de estudio.

\footnotetext{
El presente estudio recopila, matiza, condensa y corrige ciertos aspectos relacionados con los usos del ladrillo, su ciclo productivo y su reaparición a ambos lados del Sistema Central, todo ello tratado en nuestra tesis doctoral Técnicas y materiales de la construcción fortificada altomedieval en el centro de la Peninsula Ibérica: métodos de análisis a través de la arqueología y la historia de la construcción, actualmente inédita.
}

Se parte de una base compleja, ya que la homogeneidad de este grupo constructivo nos obliga a pensar en una acción o campaña de construcción relativamente corta en el tiempo, donde la dirección y promoción de la obra fueron bastante unitarias, y se incorpora de manera novedosa el uso de ladrillo nuevo, frente a otros usos donde, de modo residual, se emplean ladrillos reciclados. Esta homogeneidad pone de manifiesto que, tras un periodo de retroceso generalizado de la fabricación industrial de ladrillos, perviviendo solo de modo marginal y local, la presencia de ladrillo nuevo supone que un agente externo ha importado unas técnicas a un determinado lugar que le son ajenas. El origen de estas renovadas técnicas estaría en un enclave en el que la producción estandarizada de ladrillo estuviera plenamente asentada. Uno de estos lugares, quizá el más cercano a nuestra zona de estudio, es Toledo.

\section{EL USO DEL LADRILLO DURANTE LA ALTA EDAD MEDIA. BREVE APROXIMACIÓN}

Si sometemos a un análisis cuantitativo las técnicas constructivas altomedievales en la Península Ibérica, constatamos rápidamente cómo aquellas que incorporan ladrillo son muy minoritarias respecto a las que emplean únicamente piedra, ya sea en forma de sillería o de mampostería.

La producción de ladrillos en estos momentos es un tema que genera cierta controversia debido a la gran ausencia de datos fiables. Tanto a nivel europeo como peninsular, se tiene constatada la ralentización (incluso su desaparición) de los ciclos productivos del ladrillo a nivel general (Azuar 2005: 149-160; Caballero y Utrero 2005: 176; Quirós 1998: 235-246), con algunas excepciones puntuales. En el caso italiano, la desaparición del ladrillo se produce antes de la invasión lombarda del norte de Italia, acaecida durante la segunda mitad del siglo VI. Este material va a continuar ausente en esta zona, con salvedades, hasta aproximadamente el año 1000 (Porter 1917: 32-36). Será también en estas fechas cuando, dada la recuperación de los ciclos productivos del ladrillo, se va a comenzar a documentar el uso del aparejo de espina de pez u opus spicatum con ladrillos, como en la iglesia de San Giovanni en Vigolo Marchese (Castell'Arquato, Piacenza), datada con seguridad en torno al 1008, siendo una de los más antiguos ejemplos que atestiguan este uso (Porter 1917: 35). 
En la Península Ibérica, la fabricación de ladrillo entre los siglos VI y VII parece reducirse sustancialmente de modo generalizado (Bonet 1987: 579-580), al igual que sucede con las canteras, cuya explotación se paraliza y se pierden testimonios de actividad (Lacarra 1959: 344). La fabricación industrial de ladrillos queda reducida incluso en centros productores significativos en los siglos anteriores, como Mérida, donde se documentan usos muy puntuales desde los siglos IV y $\mathrm{V}$ a nivel arquitectónico (Durán 1999: 219). Del mismo modo, en el centro peninsular durante este mismo arco cronológico está atestiguada la producción de material cerámico de construcción a través de la documentación de hornos de tradición romana, pero de dimensiones más reducidas que en épocas anteriores, destacando la comarca de La Sagra, tanto en la zona madrileña (Juan 2016: 341), como en la toledana, donde destaca el yacimiento de "Alameda del Señorío", donde se ha podido documentar un horno dedicado a la producción local de material cerámico de construcción datable entre los siglos VI y VII (Catalán y Rojas 2009: 232). Puede deducirse que la producción de ladrillo continuó, si bien pueden ser datados y bien adscritos solo aquellos con signos identitarios definitorios, como el caso de los ladrillos con simbología cristiana impresa, con un origen norteafricano y orientados a usos funerarios principalmente, destacando su difusión en la Bética y Lusitania hasta el siglo VII (Rodríguez Neila 1988: 138-139). Habría que destacar el caso del Tolmo de Minateda (Hellín, Albacete), donde se ha podido constatar la utilización de ladrillo nuevo en paralelo al uso de material procedente del expolio de construcciones romanas en desuso para la construcción de la basílica episcopal. Se emplearon ladrillos nuevos en la construcción de la bóveda del presbiterio del templo, mientras que el material reutilizado se utilizó en los muros de las naves (Cánovas 2005: 223230; Gutiérrez y Cánovas 2009: 91-131). Será durante el siglo VIII cuando se vea un retroceso del uso del ladrillo en este yacimiento, al no documentarse su producción, siendo también el uso de spolia del todo anecdótico (Cánovas 2005: 229-230).

Otras producciones cerámicas no dedicadas a la construcción van a sufrir también un cierto retroceso. Se han documentado diversas experiencias de autoproducción a nivel local y familiar, atestiguadas sobretodo en la producción de cerámica de cocina y almacenaje, que contrastan con las producciones industriales de época romana. Puede ser el caso emeritense (Alba 2003: 293332) o el de algunos sitios arqueológicos de la zona de Madrid-Toledo (Vigil-Escalera 2007: 239-284 y 2012).
En estos momentos se documenta la producción local de cerámica de todo tipo, tanto de tipo constructiva como de mesa y cocina, utilizándose los mismos hornos para todas las producciones, lo que contrasta con la especialización de épocas precedentes, como en algunos casos del centro peninsular, datados a finales del siglo VII o principios del VIII por radiocarbono (Juan 2016: 349357). En paralelo, el uso de material constructivo cerámico procedente de reciclaje de producciones romanas precedentes va a continuar siendo la tónica dominante, predominando la teja frente al ladrillo (Vigil-Escalera 2003: 287-291).

Tras un espacio de tiempo, correspondiente fundamentalmente con los siglos VIII y IX, donde parece que la producción de material cerámico de construcción se detiene de modo generalizado tras un periodo de paulatino aletargamiento, debemos indicar el uso de ladrillo durante la segunda mitad del siglo IX en ciertas partes de los edificios del prerrománico asturiano en el entorno de Oviedo, como pueden ser arcos y bóvedas, que se pueden ver en los restos de la iglesia de San Tirso de Oviedo, San Julián de los Prados en Santullano o San Adriano de Tuñón, entre otros (Caballero y Rodríguez 2010: 112-114; Caballero y Utrero 2013: 128).

Del mismo modo, se tiene constancia de la reaparición del oficio de ladrillero asociado a grandes ciudades de al-Ándalus durante el siglo X (Cómez 2001: 38), incluso en León (Torres Balbás 1949: 257; Valdés 1984: 40). En este momento el ladrillo reaparece con módulos y métricas renovadas, optando por piezas de menor tamaño, en las que se hacen evidentes las particularidades locales según su producción. El proceso se inicia al amparo de los poderes estatales andalusíes durante el siglo $\mathrm{X}$, que tienen en Córdoba y otras ciudades un gran mercado que demanda un material de construcción barato y estandarizable.

El caso de la ciudad de Toledo y su campo es paradigmático, pues, contrariamente al resto de la península, parece que la producción y uso de ladrillos continuó de modo ininterrumpido desde la época tardorromana (Juan y Cáceres 2010: 91-99), una circunstancia explicada tanto por la continuidad de las poblaciones anteriores como también por su rápida integración en los circuitos productivos y comerciales del emirato, a pesar de su condición alejada y levantisca ${ }^{3}$. Hacia el

\footnotetext{
3 Más datos sobre la historia del Toledo islámico pueden obtenerse de diferentes contribuciones, destacando entre otras muchas: Crego 2007; Delgado 1987a; Ruiz Taboada 2012.
} 
año 1000 , se puede asegurar que el ciclo productivo del ladrillo estaba perfectamente asentado y desarrollado, atestiguado por la mezquita de Bab al-Mardum o del Cristo de la Luz, reformada según su epígrafe en el año 999. De este modo, la fabricación industrial de ladrillo va a alcanzar unas cotas muy significativas a partir de la segunda mitad del siglo XII a través de la proliferación de iglesias debido a la extensión de la red parroquial, lo que es conocido como románico "mudéjar" (Abad 1991; Araguas 2003 y 2005: 161-168; Valdés 1984).

\section{LA MAMPOSTERÍA ENCINTADA CAJEADA. CARACTERÍSTICAS Y DISTRIBUCIÓN DE EJEMPLOS}

La particularidad de la mampostería encintada "cajeada", técnica constructiva objeto de revisión en el presente estudio, reside en la combinación del uso de mampostería de tamaño medio, muy irregular, con ladri1lo. Esta mampostería mixta se caracteriza por separar con una verdugada doble de ladrillos cada una de las hiladas de mampostería, a la par de contar con ladrillos a sardinel entre cada uno de los mampuestos, a modo de tabica vertical, ofreciendo de este modo un aspecto exterior metopado, una secuencia alterna armónica entre ladrillos mostrando su tizón y un mampuesto de proporciones cuadrangulares. Los lugares en los que se ha documentado este aparejo son, en Guadalajara: Humanes de Mohernando (despoblado de Peñahora), Cogolludo (castillo) y Jadraque (castillo). En Madrid se han documentado únicamente en Buitrago de Lozoya (murallas) y Talamanca del Jarama (arrabal extramuros de la calle San Isidro e iglesia de San Juan Bautista), en la provincia de Segovia: Ayllón (castillo, Arco de la Villa e iglesia de San Miguel), Fresno de Cantespino (ruinas del castillo), Fuentidueña (Puerta de Alfonso VIII o de Trascastillo) y Sepúlveda (Torre de San Andrés), entre otros dudosos o menos significativos (Fig. 1).

Esta técnica constructiva fue documentada por primera vez por Alonso Zamora Canellada (1993), que puso el punto de atención en esta técnica asociada mayoritariamente con elementos fortificados, relacionados tanto con reparaciones de fortificaciones preexistentes como con edificios de nueva planta, y que propone vincular al mundo andalusí. Zamora inicia sus investigaciones en este campo con las excavaciones del castillo de Ayllón en los años 80, que culminan con la publicación de la monografía sobre estos trabajos (1993) que había

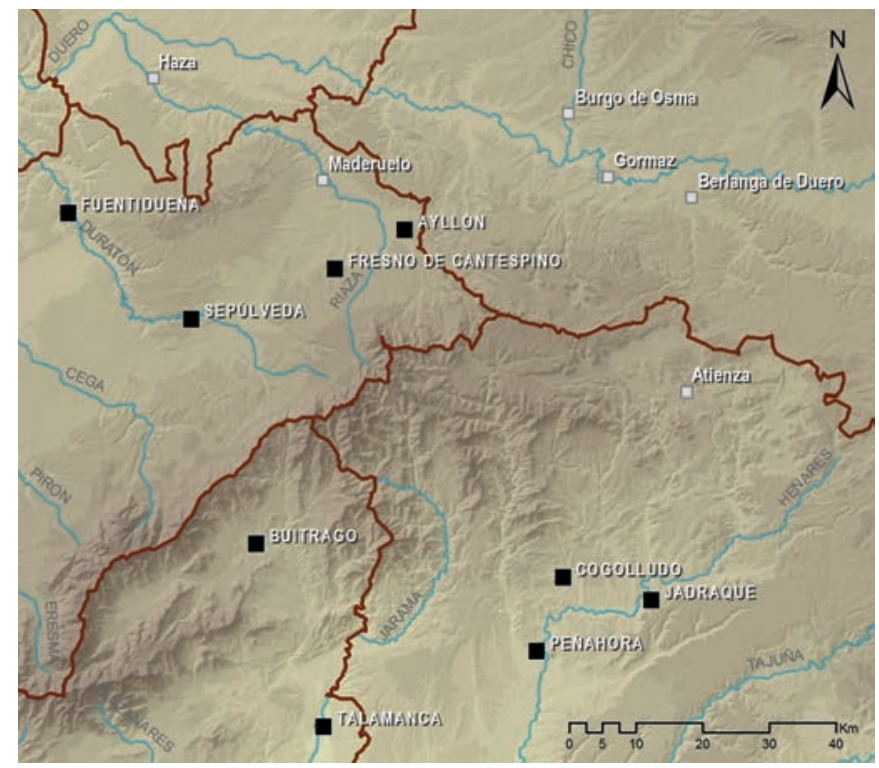

Figura 1. Mapa del Sistema Central peninsular, correspondiente a parte de las provincias de Guadalajara, Madrid, Segovia y Soria, en el que se localizan los edificios en los que se ha documentado la mampostería encintada cajeada (cuadrado negro). Fuente: elaboración propia.

sido también el tema de su tesis doctoral. Antes ya se había adentrado ya en el complejísimo conjunto fortificado de Sepúlveda, que fue objeto de publicación monográfica (Martín, Tardío y Zamora 1990), donde particulariza brevemente en la singularidad de la Torre de San Andrés, construida con mampostería encintada cajeada, y los edificios que presentan esta misma técnica en el entorno del oriente segoviano. A partir de estos trabajos, Zamora va a tratar de modo pormenorizado este aparejo en otros artículos, donde va a ir aumentando la nómina de ejemplos, a tenor de los nuevos documentados, ajustando la reflexión y propuesta cronológica (1998), así como proponiendo paralelos formales lejanos, como algunas iglesias griegas de la zona de Tesalónica edificadas en el siglo XI-XII, así como otros ejemplos en el Cáucaso (Zamora 1993: 125 y 1998: 775). Del mismo modo, también ha ido reduciendo la nómina inicial, eliminando por dudosos lugares como la torre de El Salvador de Segovia, la alcazaba de Almería, la alcazaba de Málaga, el castillo de Cogolludo, el castillo de Consuegra, el castillo de Escalona y el castillo de Alcalá de Guadaira (Zamora y Vela 2005: 1141-1142). En paralelo a los trabajos de Zamora existen propuestas que abogan por una filiación castellana para este aparejo, siendo de este modo fruto de la repoblación temprana en los extremos del Duero en una cronología similar, siglos X-XI (Jiménez 2005: 633-640). 
Con posterioridad, la nómina de ejemplos ha aumentado con dos aportaciones al sur del Sistema Central muy significativas. La primera fue localizada en el castillo de Jadraque en Guadalajara (Daza 2001 y 2005) tras el movimiento de tierras realizado para la pavimentación de la rampa de acceso y la colocación de un monolito de la ruta del Camino del Cid. El segundo localizado, el único hasta la fecha relacionado con espacios domésticos y con una estratigrafía arqueológica asociada, fue efectuado en la calle San Isidro de la localidad de Talamanca del Jarama en Madrid durante los trabajos de urbanización del espacio ${ }^{4}$.

\section{Guadalajara}

El castillo de Peñahora (Humanes de Mohernando) cuenta con evidencias de este aparejo que suponen el hallazgo más meridional dentro la zona de estudio hasta el momento. Se trata de un recinto fortificado de considerables dimensiones localizado sobre un promontorio amesetado ubicado en la confluencia de los ríos Sorbe y Henares. Ha sido identificado con la fortaleza (Hișn) de Peñafora o Binna Furata, fundada por iniciativa del emir Muhammad I entre los años 853 y 865 junto con Mayrit (Madrid), Talamanka (Talamanca del Jarama) e Istiras (probablemente, Esteras de Medinaceli, Soria), entre otros (Ibn Hayyān 1973: 132). Hay varias hipótesis sobre las razones de su fundación. Por un lado, se ha propuesto que su función sería controlar los caminos que comunicaban el valle del Duero con Toledo, a fin de evitar el apoyo norteño a las constantes revueltas toledanas (Manzano 1991: 168-171; Torres Balbás 1960: 242). Otra hipótesis sobre la fundación de estas fortificaciones es que fueron realizadas por el linaje beréber de los Banu Salim como delegados del poder emiral en un intento de reorganizar su espacio, atenazado por otros linajes beréberes tanto al norte como al sur (Bermejo y Muñoz 1994: 220-225). Del mismo modo, también se ha propuesto que este proyecto emiral sería un elemento de presión fiscal sobre los habitantes de la "frontera de Toledo" (Mazzoli-Guintard 2011: 51-57).

En cuanto a su morfología, consta de tres recintos diferenciados que en la actualidad están muy desdibujados. Un recinto superior, considerado propiamente como el castillo, del que no quedan restos visibles. El segundo, por debajo del primero, desarrolla una mayor amplitud,

\footnotetext{
4 Esta excavación fue realizada bajo la dirección de Miguel Ángel García Valero y Elena Vega Rivas entre los años 2005 y 2007.
}

por lo que ha sido considerado como el recinto de una puebla. Un tercer recinto, el más bajo, localizado fuera del cerro junto al río, delimitaría posiblemente zonas de arrabal del asentamiento principal (Jiménez 1992: 283-291; Pavón 1984: 96-101). Los restos constructivos visibles más significativos se encuentran en el segundo recinto, tanto en su esquina norte, donde se conserva una posible puerta con restos de sillería, como en el extremo sur, correspondientes a la parte inferior de una torre esquinera realizada en mampostería encintada cajeada. Se documentan tres hiladas de esta mampostería, así como una esquina construida por entero en ladrillo de un muro de doble hoja con núcleo de relleno de piedras con mortero de cal. La mampostería cuenta de doble verdugada de ladrillo y tabicas de ladrillo a sardinel, utilizando como mampuestos cantos de cuarcita. De media, los ladrillos miden $28 \times 20 \times 4 \mathrm{~cm}$ y los tendeles un grosor de $4 \mathrm{~cm}$, mientras que las llagas están entre 1 y 2 cm (Fig. 2.1).
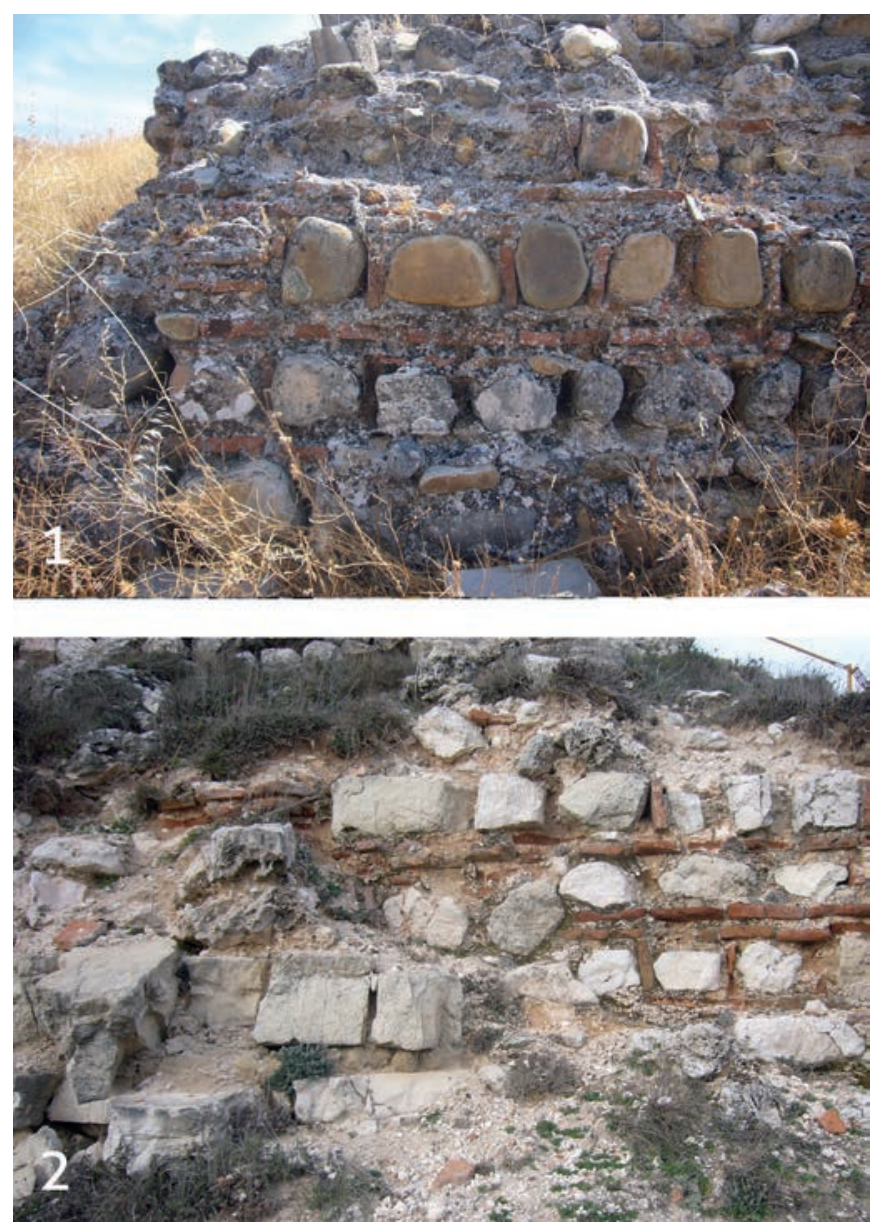

Figura 2. Ejemplos de mampostería encintada cajeada en la provincia de Guadalajara: 1) Restos documentados en Peñahora (Humanes de Mohernando); 2) Paramento localizado en el acceso del castillo de Jadraque. Fotografías del autor (2014). 
El caso documentado en el castillo de Jadraque es muy similar (Daza 2005: 803), ya que también conserva unas pocas hiladas sobre la cimentación y parte de una de sus esquinas. Se localiza al sur del conjunto, inmediato a la puerta de la fortificación bajomedieval. Los ladrillos miden aproximadamente $29 \times 19 \times 4,5 \mathrm{~cm}$ y los tendeles tienen un grosor de $4 \mathrm{~cm}$, mientras que las llagas están entre 1 y $2 \mathrm{~cm}$ (Fig. 2.2). A diferencia de Peñahora, el material de la mampostería es caliza, procedentes del propio cerro. Los restos no presentan en la actualidad conexión estratigráfica con el castillo bajomedieval y parece que fueron amortizados cuando se construyó en la segunda mitad del siglo XV, si bien aún debían ser visibles cuando B. Castellanos de Losada visita el castillo a finales del siglo XIX, pues menciona un paramento de "estilo de construcción árabe" (López-Muñiz 2003: 88). Estos restos para Prieto y Retuerce (2008: 18) son claramente andalusíes, perfectamente conectados con los restos cerámicos recuperados de los silos excavados en el interior del castillo.

Por el contrario, los restos de este aparejo en el castillo de Cogolludo presentan ciertas diferencias (Fig. 3), aunque no suficientes para excluir del grupo este ejemplo (Zamora y Vela 2005: 1141-1142). Este castillo, que se encuentra situado al norte del casco urbano, en el extremo este de El Lomo, es una fortificación de pequeño tamaño, que formaba parte del recinto amurallado de la villa de Cogolludo, a modo de reducto (Jiménez 1992: 152-156; Pavón 1984: 116-120; Retuerce 1983: 74-75). En la parte meridional destaca una de las torres, realizada parcialmente en aparejo encintado. Esta torre es un elemento muy singular, preexistente en la configuración actual del castillo, puesto que sus muros son estratigráficamente posteriores a la torre. Es de planta cuadrada al exterior y circular al interior, rematada por una cúpula de ladrillo, contando con un único vano en su fachada norte. Tras los estudios realizados, esta torre se ha identificado con la "torre de la campana" que menciona la documentación del siglo XVI, por lo que se ha propuesto que se trate de una torre campanario oculta por escombros casi en su totalidad, viéndose actualmente solo su parte superior. Por la antigüedad del aparejo, del enclave y tomando su denominación en las fuentes, se ha propuesto que puede tratarse de un alminar, de cronología bastante arcaica ya que la caja de escalera que mostraría sería cilíndrica, como en algunos alminares emirales y califales, que formaría parte de un conjunto fortificado vinculado a un oratorio, quizá vinculado al ejercicio del ribāt en la Marca Media (Daza 2015: 100-110 у 2018: 279).

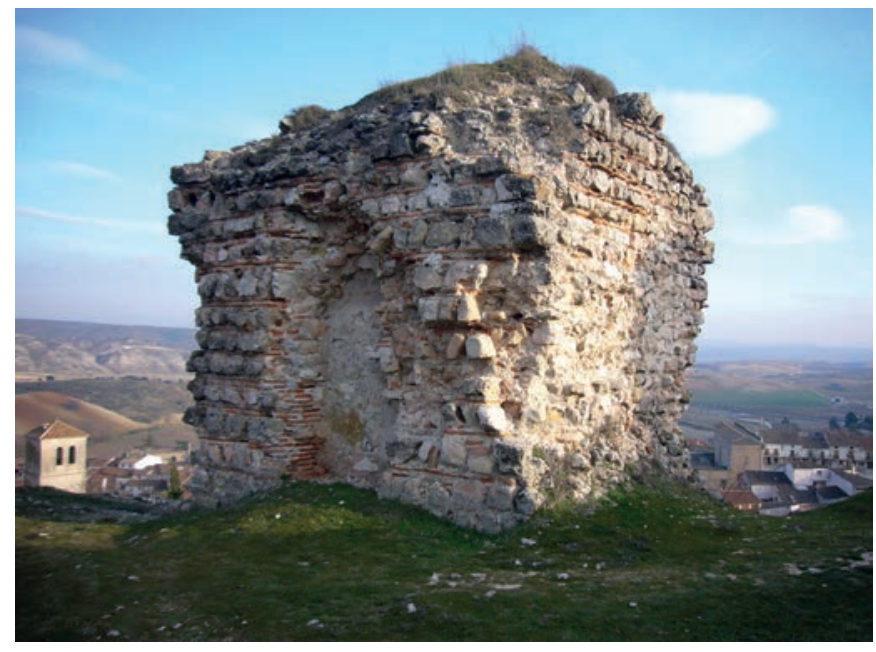

Figura 3. Torre de la Campana en el castillo de Cogolludo (Guadalajara). Fotografía del autor (2007).

En cuanto al aparejo encintado, en el caso de Cogolludo se sale de la pauta prototípica que vemos en Jadraque y en Peñahora, así como en los ejemplos segovianos (vid. infra) ya que las hiladas están mal reguladas, la mampostería no es homogénea, en ocasiones no muestra la doble verdugada de ladrillo y no cuenta con demasiados ladrillos a sardinel que confieran al aparejo su característico despiece. Además, las esquinas de la torre son de piedra, lo que contrasta con el resto de ejemplos, donde las esquinas conservadas son de ladrillos. Las fachadas oeste y norte de la torre son las que muestran un aparejo más cuidado, mientras que las otras, que cuentan con mampostería y sillería reutilizada, es más irregular, más cercano a una mampostería atizonada que emplea calzos de ladrillo y teja. Quizá se trate de un edificio más antiguo, en el que se estén empleando todavía materiales reutilizados más antiguos combinados con ladrillos nuevos. Los ladrillos empleados en esta torre adolecen de uniformidad, ya que los más cuidados (empleados en las dobles verdugadas de ladrillo, enmarcando hiladas de mampostería de aproximadamente $30 \mathrm{~cm}$ de altura) cuentan con unas dimensiones similares a Jadraque y Peñahora $(29 \times 19 \times 4,5 \mathrm{~cm})$, mientras que algunos ladrillos medidos en la esquina suroeste de la torre cuentan con unas dimensiones mayores $(31$ x 22 x 5,5 cm). Para Zamora y Vela (2005: 1141-1142) estas variaciones suponen su salida de este grupo tecnológico y proponen que no se trataría de una construcción andalusí si no una obra mudéjar, tal y como proponía Pavón (1984: 116-120). 


\section{Madrid}

La muralla de Buitrago de Lozoya es, sin lugar a dudas, el mejor ejemplo de este tipo de técnica constructiva, a tenor de su extensión y su uniformidad, al menos en su fase inicial. El recinto amurallado, localizado sobre una loma de cierto escarpe que se adentra en un meandro del río Lozoya, cuenta con un recinto principal que genera un reducto aprovechando el citado meandro. Este recinto conserva 14 torres, siendo la sexta la que contiene la Puerta de la Villa o Torre del Reloj, conservando todas ellas restos de la mampostería encintada cajeada relacionada con la primera fase del conjunto, conformado por un lienzo de tapial calicastrado con torres de flanqueo y una puerta de acceso recto realizados todos ellos con esta mampostería (AA. VV. 1993: 132-143; Pastor 2008: 52-61). Con posterioridad, probablemente durante el siglo XII, la muralla se reparó mediante un forro de tapia de cal y canto, tanto interior como exteriormente, amortizando el adarve y el parapeto almenado realizados en la fase anterior, ocultando gran parte de los vestigios del aparejo encintado (Fig. 4). Del mismo modo, en el siglo XIV se reparó la puerta, convirtiéndola en un acceso en codo incorporado a una torre pentagonal (Daza 2015: 110118). Esta puerta es, con diferencia, el elemento más interesante del conjunto, ya que sirvió como eje organizador de la defensa, puesto que pudo ser el único acceso al adarve de todo el recinto. La puerta original era de acceso recto enmarcado por dos torres y estaba realizada completamente con mampostería encintada cajeada con dobles verdugadas de ladrillo, con cadenas de ladrillo conformando las esquinas, contando con caja de rastrillo para cerrar el paso (Fig. 5). De hecho llama la atención que las torres de flanqueo, que aparentemente tienen un aparejo similar, suprimen una de las verdugadas de ladrillo, por lo que es posible que imiten el aparejo de la torre, por consiguiente, más antiguo.

En cuanto a los vestigios localizados en Talamanca del Jarama, concretamente en la calle San Isidro, es muy significativo que se hayan localizado restos de muros realizados en este aparejo en contexto estratigráfico, conformando las estructuras habitacionales de un arrabal extramuros de la madina, que pone de manifiesto su desbordamiento durante la segunda mitad del siglo X, y su ocupación hasta mediados del siglo XII, cuando es abandonado de manera rápida ${ }^{5}$ (Fig. 6.1 y 6.2).

\footnotetext{
5 Estos trabajos supusieron la documentación de varias unidades habitacionales extramuros, que contaban con varias estancias, patios, atarjeas..., en relación con materiales arqueológicos muy significativos, desde ollas de escotadura, candiles de piquera, vidriados melados... hasta piezas completas realizadas con cuerda seca total y parcial.
}

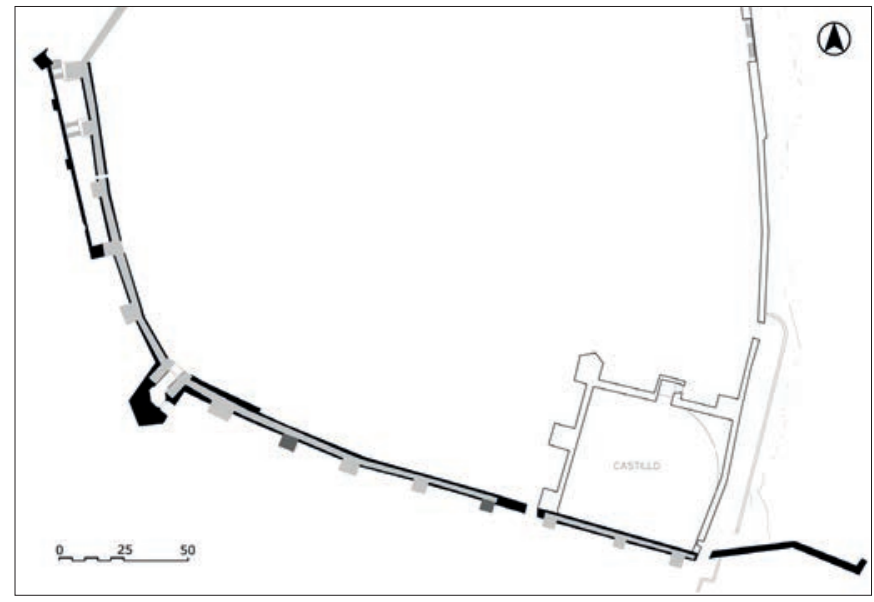

Figura 4. Planta general del conjunto amurallado de Buitrago de Lozoya (Madrid), indicando en gris claro el trazado altomedieval realizado en mampostería encintada cajeada y tapia de tierra calicastrada. En gris oscuro, las torres de esta fase no conservadas, y en negro, las reformas pleno-bajomedievales. Elaboración propia a partir de planimetría catastral.

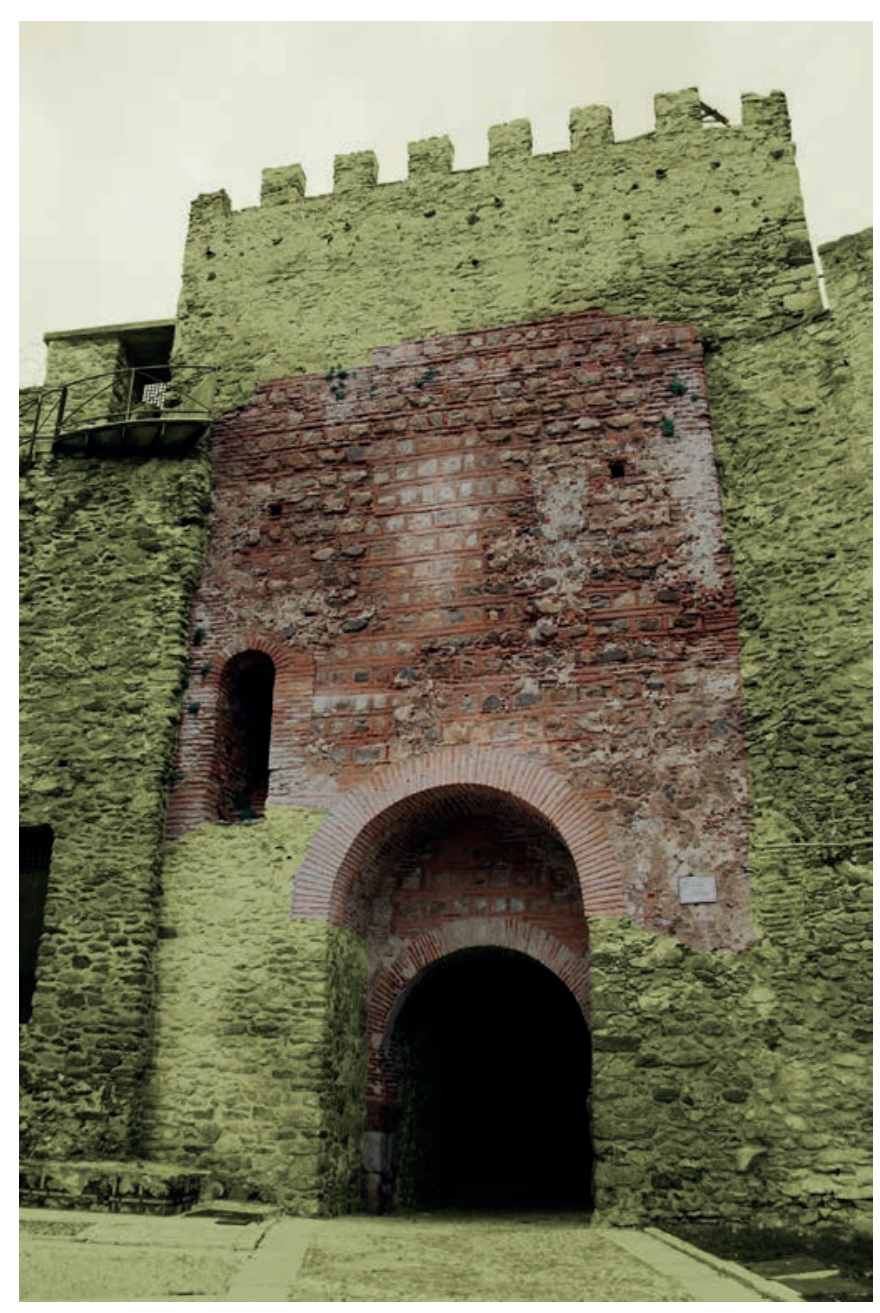

Figura 5. Vista general intramuros de la Puerta de la Villa de la muralla de Buitrago de Lozoya, indicando la fase altomedieval del paramento. Fotografía y composición del autor (2015). 

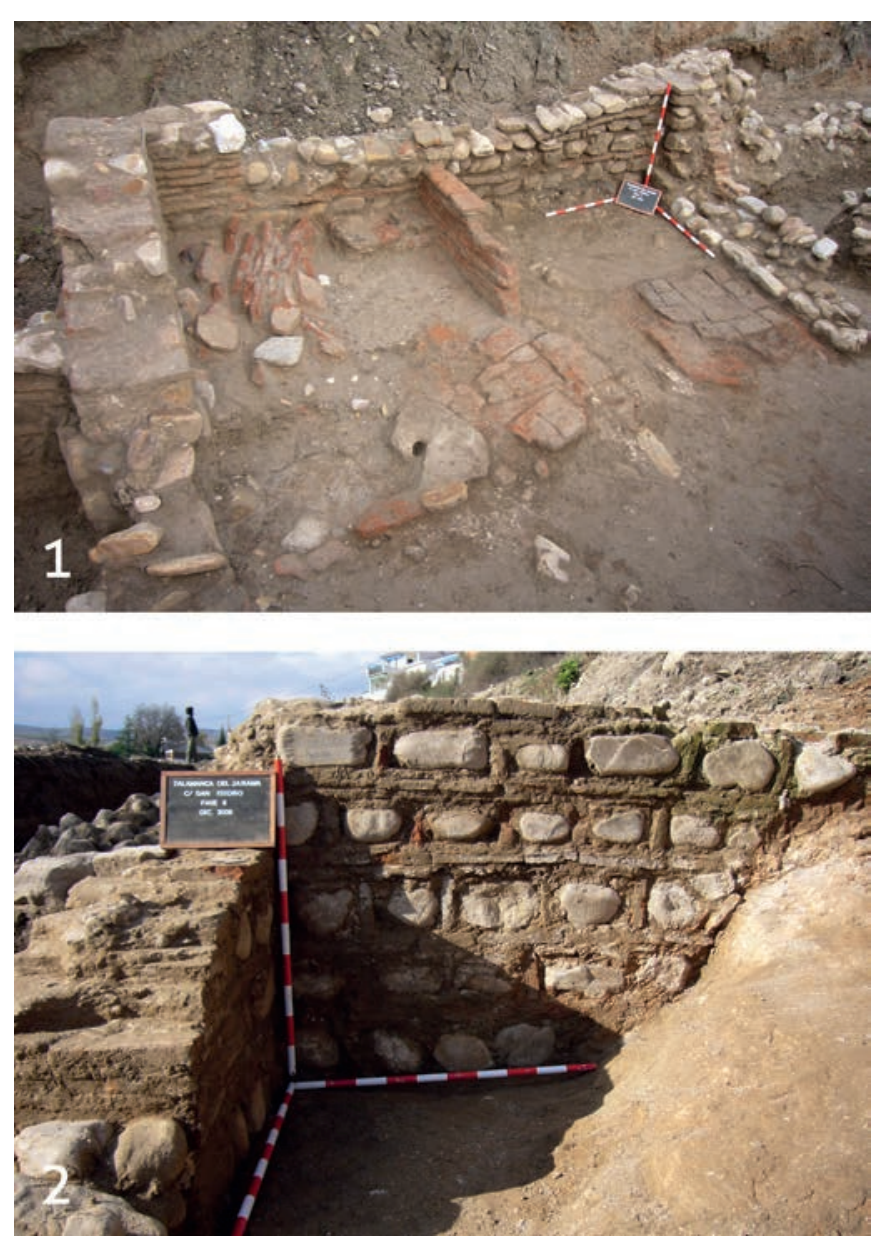

Figura 6. Trabajos arqueológicos realizados en la calle San Isidro de Talamanca del Jarama, Madrid, realizados entre 2005 y 2007: 1) Vista general de uno de los espacios de habitación localizados durante la excavación; 2) Detalle de uno de los muros realizado con mampostería encintada cajeada. Fotografías cortesía de Elena Vega.

A los restos en calle San Isidro habría que sumar los documentados en la iglesia de San Juan Bautista, ciertamente dudosos $\mathrm{y}$, hasta la fecha, también inéditos. Se trata de un templo de origen plenomedieval que conserva uno de los únicos ábsides románicos en piedra de la región. Conserva restos en la fachada norte que permiten observar cómo un edificio preexistente al edificio románico fue aprovechado para la construcción de este templo. Este será ampliado en dos ocasiones hacia los pies, tal y como se observa en el paramento citado. También se puede observar cómo hubo que reelevar los muros para la colocación de la armadura de madera y el coro que hoy presenta. El aparejo documentado es una secuencia de cantos de rio con ladrillos a sardinel sin verdugadas horizontales que fue objeto de restauraciones a principios de los años 80 . Además, se puede ver que algunas verdugadas de ladrillo están completamente repuestas (Daza 2015: 392-393) (Fig. 7.1 y 7.2).
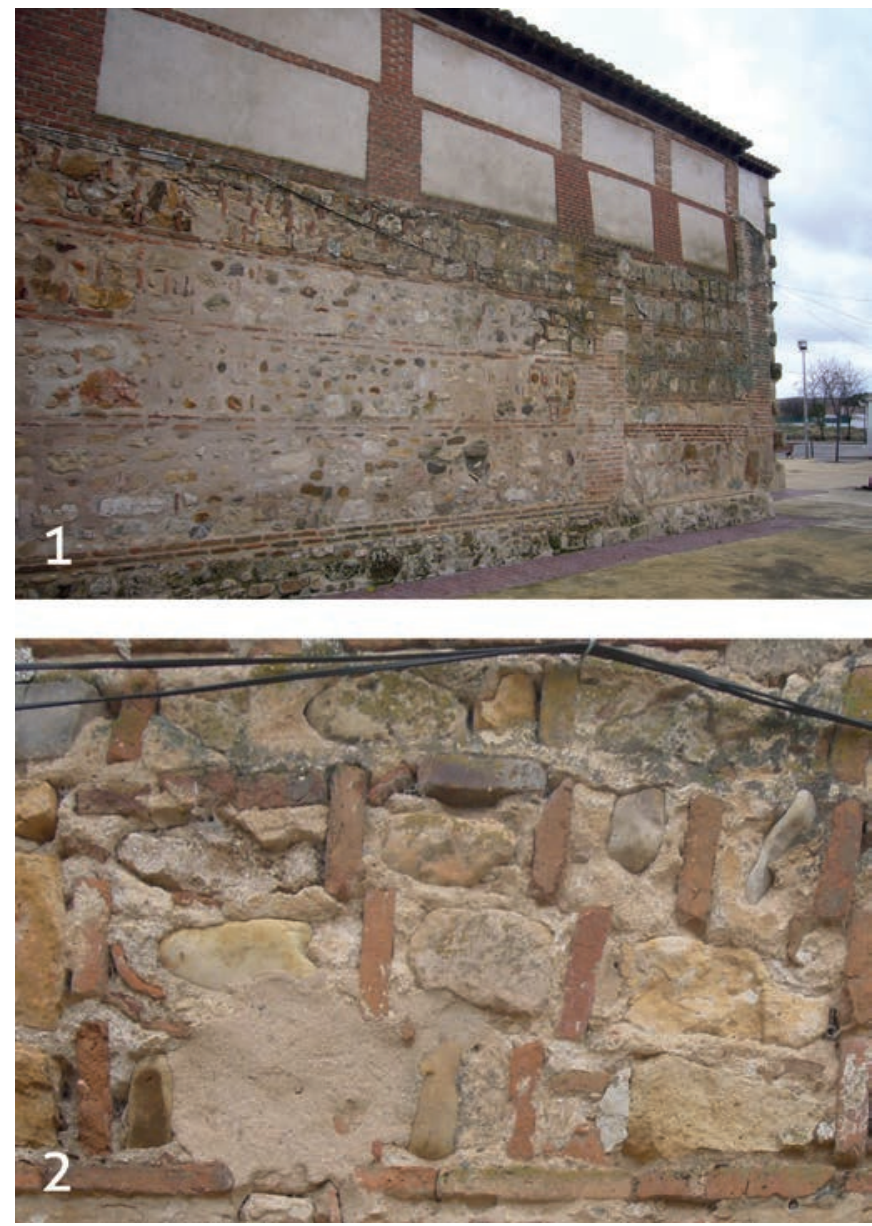

Figura 7. Iglesia de San Juan Bautista en Talamanca del Jarama: 1) Vista general de la fachada norte; 2) Detalle del aparejo conservado en su fachada norte. Fotografías del autor (2008).

\section{Segovia}

Los ejemplos documentados en la provincia de Segovia son los más numerosos de la muestra, siendo además los que más datos ofrecen a fin de dar una explicación a la aparición y difusión de esta técnica constructiva.

Los vestigios del Cerro del Castillo o de La Martina en Ayllón fueron los primeros en ser documentados por Zamora (1993) en los años 80 (vid. supra). El recinto fortificado, que bien podría considerarse una muralla urbana, delimitaba un espacio de 2,8 ha, que a su vez pudo contar con algún reducto a modo de castillo propiamente dicho (Jiménez 2005: 633-640). Las excavaciones, pese a lo degradado del yacimiento, permitieron fechar el conjunto en torno a los siglos $\mathrm{X}$-XI, aunque su estado de ruina avanzada no permite establecer secuencia segura alguna debido a la desconexión estratigráfica de los elementos emergentes. En cuanto a los restos de mampostería 
encintada cajeada, están muy arrasados, conservándose solo tres hiladas de mampostería de cantos y ladrillo sobre tapia de tierra. Los ladrillos miden 29 × 20 x $4 \mathrm{~cm}$ y los tendeles cuentan con un grosor de $4 \mathrm{~cm}$, mientras que las llagas están entre 1 y $2 \mathrm{~cm}$, medidas y proporciones similares a los observados en otros enclaves estudiados (Cobos, Retuerce y Hervás 2001: 759-773; Serrano y Tremiño 1989: 341-348; Zamora 1993 y 1998).

Los vestigios de este aparejo en el castillo no son los únicos asociados a las fortificaciones de la villa. En una de las torres de flanqueo del Arco de la Villa (Fig. 8), una de las puertas de la muralla inferior de Ayllón (Jiménez 2005: 637), frente al puente que salva el río Aguisejo, se pudo documentar de nuevo (Zamora 1993: 90-91 y 1998: 763-764). Trabajos de restauración recientes en la puerta han retirado capas de cemento que ocultaban el despiece y han puesto de manifiesto que contaba con este aparejo, al menos, en la fachada exterior de la torre sur. La puerta fue muy transformada en época bajomedieval con mampostería concertada, incorporando un arco de sillería a modo de buhedera, sobre la cual se instaló posteriormente una ladronera. En época moderna las casas ocuparon espacio extramuros, de manera que enrasaron las torres, desdibujando su perfil y perdiendo su función de flanqueo (Zamora 1993: 128). Esta puerta fue un acceso recto enmarcado por torres cuadrangulares macizas, al igual que la Puerta de Alfonso VIII de Fuentidueña o la Torre del Reloj de Buitrago. Estaba realizada con mampostería encintada cajeada con doble verdugada de ladrillo y con esquinas de ladrillo, similar a los restos del recinto superior. Actualmente, tras la últimas labores de restauración, se han enrasado las llagas con mortero, por lo que es difícil observarlo.

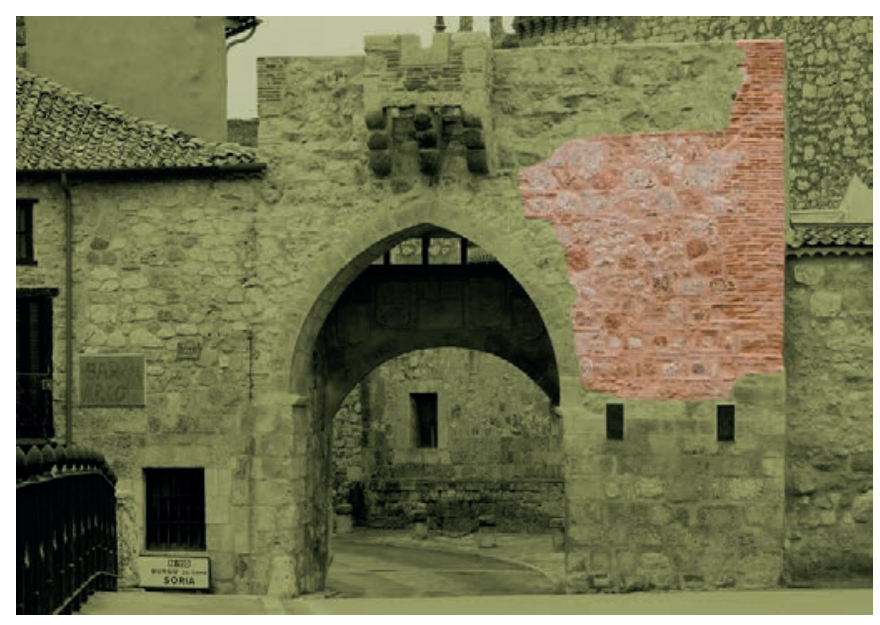

Figura 8. Fachada exterior del Arco de la Villa de la muralla de Ayllón, inmediata al cauce del río Aguisejo tras su última restauración. Fotografía y composición del autor (2015).
El último de los vestigios documentados en Ayllón fue localizado en la iglesia de San Miguel, un edificio de traza románica de una sola nave ubicado en el centro del casco urbano, dentro del recinto amurallado inferior, en uno de los extremos de la Plaza Mayor. Este edificio fue objeto de restauración integral en torno a $1996^{6}$ (Maldonado y Vela 1998: 99-103), momento en el que se puso de manifiesto que el templo se edificó hacia 1200 (AA. VV. 2006: 324) sobre un edificio preexistente, que tendría una anchura algo mayor que la nave actual, y que estaría realizado en mampostería encintada cajeada. Los paramentos preexistentes se localizan tanto en la fachada sur de la iglesia como en la esquina nororiental de la nave. En esta última se ha conservado una esquina del edificio anterior, hasta una altura de $5 \mathrm{~m}$ con una anchura aproximada de $0,80 \mathrm{~m}$, visible tanto al interior como al exterior (Fig. 9.2 y 9.3). Mismo caso el de la fachada sur, que a pesar de no haberse conservado tanta altura, si cuenta con más longitud, llegando hasta la puerta de entrada (Fig. 9.1 y 9.4). Este paramento cuenta con mechinales de andamio de sección cuadrada, perfectamente cajeados en la fábrica. Llama la atención que los restos descubiertos conformando una esquina del edificio anterior al templo conservan un llagueado de mortero de cal que enrasa el ladrillo y redondea los mampuestos (Zamora y Vela 2005: 1137-1154). Estos restos, aunque presenten similitudes formales con el resto de edificios descritos, la masividad de la construcción es notablemente inferior, a la par que se trata de un edificio de mayores dimensiones que los demás, por lo que es muy posible que no se trate de un edificio defensivo. Su ubicación topográfica también soportaría esta hipótesis (Daza 2015: 510-511). San Miguel de Ayllón también es el único que aporta una datación ante quem para el grupo, ya que conocemos aproximadamente la fecha de construcción del templo, en torno al año 1200, momento en el que la construcción preexistente ya se encontraba en avanzado estado de ruina (Zamora 2011: 177-188).

Del mismo modo, los restos de este aparejo en el castillo de Fresno de Cantespino son especialmente relevantes (Zamora 1993: 104-106 y 1998: 765), a pesar de su mal estado de conservación. Los restos del castillo se localizan en el lado sur de la cumbre de un cerro, en cuya falda norte se asienta la población. Se desconoce la fisonomía exacta de la construcción, ya

6 Estos trabajos de rehabilitación contaron con un control arqueológico efectuado por Esther Villafruela Arranz y Fernando Vela Cossío, a quienes agradezco muy sinceramente que me facilitaran la consulta de la documentación y el material gráfico que recabaron durante los trabajos. 

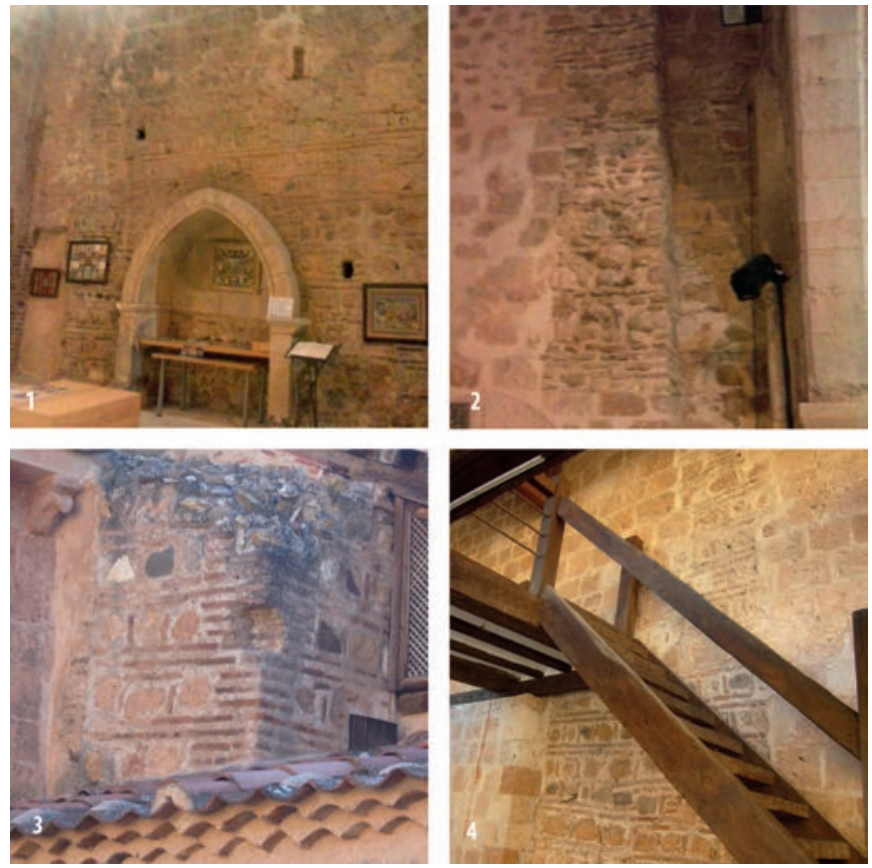

Figura 9. Varios detalles de los vestigios de mampostería encintada cajeada localizados en la iglesia de San Miguel de Ayllón: 1) Fachada sur interior; 2) Esquina noreste vista desde el interior; 3) Esquina noreste vista desde el exterior; 4) Restos en la fachada sur exterior vista desde el atrio. Fotografías del autor (2015).

que fue prácticamente desmontado durante unos trabajos de extracción de arcillas, que dejaron como único resto visible tres hiladas de mampostería de un muro de doble hoja, de desarrollo curvo, sin trasdosar al exterior, realizado en mampostería encintada cajeada (Fig. 10). Los ladrillos miden en su mayoría 29 × 20 × $4 \mathrm{~cm}$ (33 en algún caso puntual) y los tendeles un grosor de $4 \mathrm{~cm}$, mientras que las llagas están entre 1 y $2 \mathrm{~cm}$, muy similar a otros ejemplos de este tipo constructivo. El relleno del muro es de cantos de rio de diferente centil y fuerte mortero de cal y arena. El estado de conservación de los restos impide clasificar su funcionalidad, si bien una excavación arqueológica de los restos que se insertan en el talud pudiera arrojar nuevos datos sobre un resto tan singular?.

Otro ejemplo, el más septentrional del conjunto estudiado, se localiza en la Puerta de Alfonso VIII, o de Trascastillo, de la muralla de Fuentidueña, en la margen izquierda del río Duratón (Fig. 11.1). La muralla recorre la parte más llana al sur, para ir descendiendo hacia el valle, encerrando el casco urbano (Sainz 2017: 235-296).

\footnotetext{
En la actualidad, estos restos están siendo objeto de trabajos de limpieza y excavación por iniciativa de la Junta de Castilla y León. Esperamos que estas actuaciones sean fructíferas y que posibiliten la interpretación y publicación de unas estructuras tan singulares como estas.
}

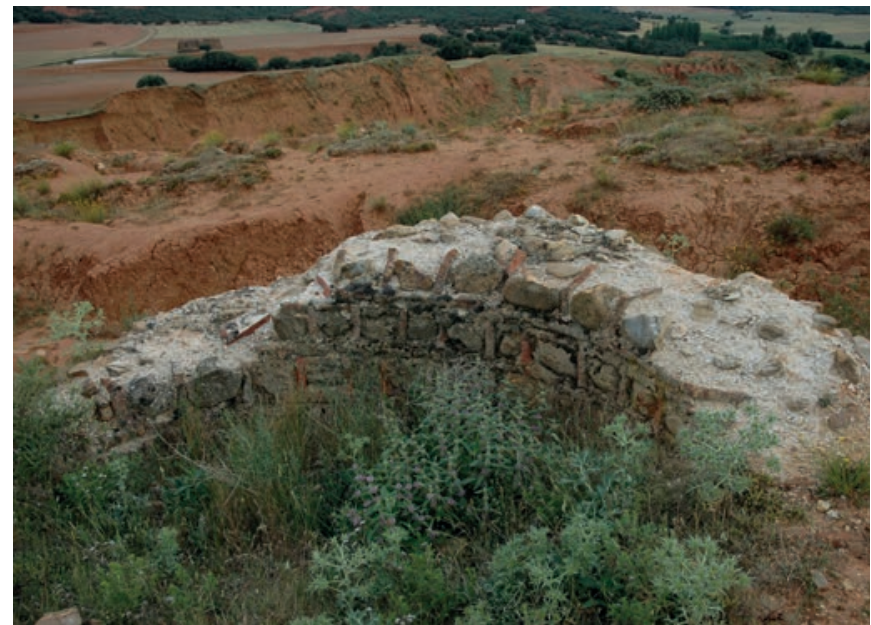

Figura 10. Restos de la fortificación de Fresno de Cantespino, realizados en mampostería encintada cajeada. Fotografía de Gonzalo López-Muñiz (2009).
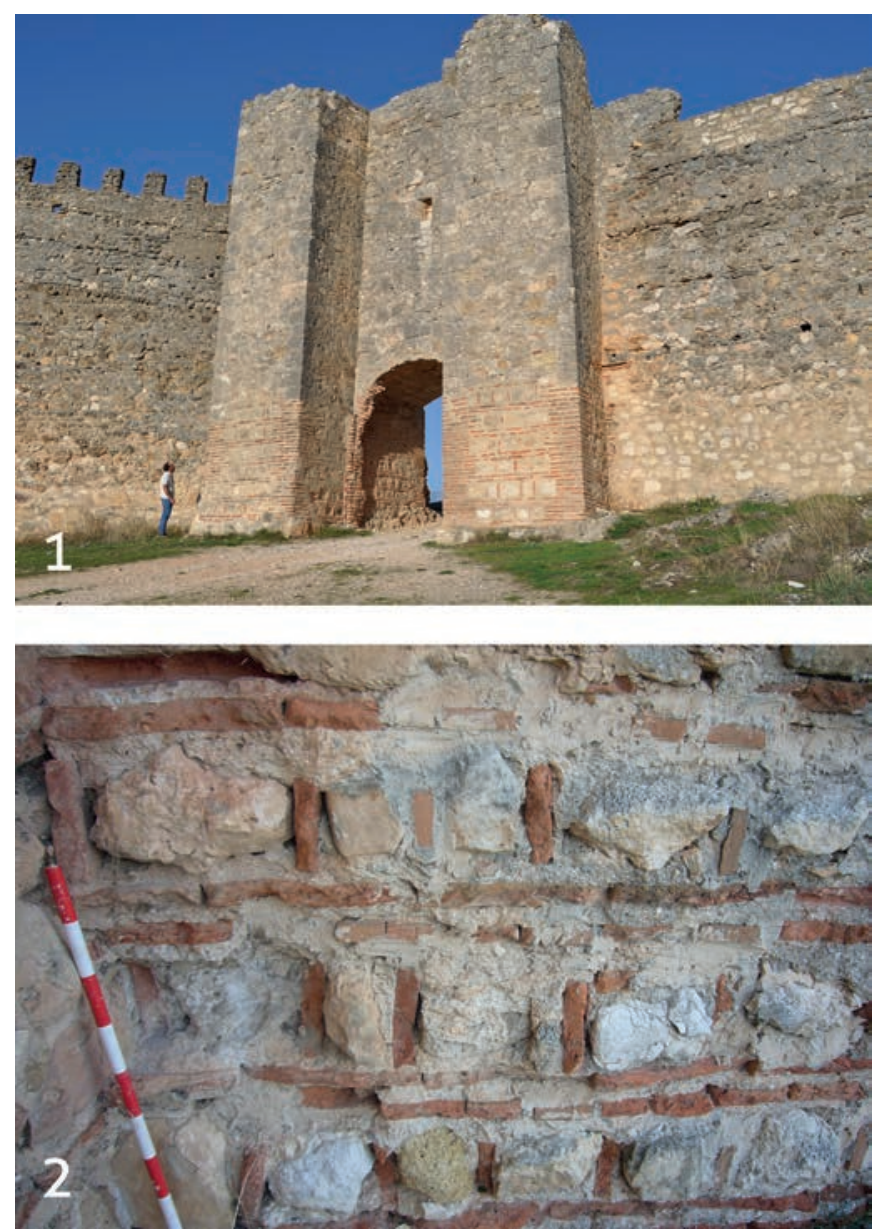

Figura 11. Puerta de Alfonso VIII o de Trascastillo, localizada al sur del conjunto amurallado de Fuentidueña, Segovia: 1) Vista general desde el exterior, donde se pueden ver los restos de mampostería encintada cajeada conservados en su parte inferior; 2) Detalle de los restos de este aparejo localizados intramuros. Fotografías del autor (2014). 
En el entorno de la Puerta de Alfonso VIII se detecta que la parte inferior de las torres y el paso de la puerta pertenecen a una fase inicial, a la que posteriormente se le adosan los lienzos murarios de mampostería encofrada, probablemente en sustitución de otra (Zamora 1993: 104-106 y 1998: 765). La parte inferior de la puerta está realizada en mampostería encintada cajeada, cuyos ladrillos miden $34 \times 18 \times 4 \mathrm{~cm}$ y los tendeles un grosor de $4 \mathrm{~cm}$, mientras que las llagas están entre 1 y $2 \mathrm{~cm}$ (Fig. 11.2). Se detectan otras medidas diferentes muy dispares, pudiendo tratarse de reparaciones posteriores. Se trata de una puerta de acceso recto enmarcado por dos torres cuadrangulares y macizas que se proyectan hacia el exterior, que contaba con un paso compuesto de dos arcos (interior y exterior) con caja para rastrillo en el centro del paso. Es muy similar, tanto métrica como compositivamente, a las puertas del Arco de Ayllón y la Torre del Reloj de Buitrago. Incluso cuenta con un rastrillo al interior del paso como en Buitrago.

\section{La Torre de San Andrés de Sepúlveda como síntesis constructiva de un proceso}

Esta torre, localizada en el extremo occidental del casco urbano de Sepúlveda, a pocos metros al norte de la Puerta de Duruelo (Fig. 12) es el edificio de mayor tamaño y más completo de cuantos integran este conjunto a día de hoy. La Torre de San Andrés, además de emplear la mampostería encintada cajeada de modo principal, conserva sistemas constructivos complejos, por lo que merece una aproximación pormenorizada. Es un edificio conocido de antiguo, considerado como la antigua torre campanario de la parroquia de San Andrés, que desaparece de la historia de la villa a principios del siglo XVIII, momento en el que pasa a convertirse en vivienda, función que ha desempeñado hasta hace poco tiempo (Martín, Tardío y Zamora 1990: 83) ${ }^{8}$.

Se trata de una construcción de planta cuadrangular, con unas dimensiones exteriores de aproximadamente 7 x $7 \mathrm{~m}$, y 13 de altura, construido por completo con mampostería encintada cajeada con esquinales realizados

\footnotetext{
8 Durante los meses de septiembre y octubre de 2016 se han efectuado trabajos de excavación arqueológica y lectura de paramentos en la torre realizados por la empresa de arqueología GROMA y asesorados por el Dr. Alonso Zamora. La noticia preliminar de estos trabajos puede ser seguida en la web http://torredesanandres.blogspot.com.es/. Ponen de manifiesto una fase románica, probablemente adscrita a la conversión de este edificio en parte de una parroquia medieval, su torre campanario, a tenor de los restos de enterramientos y los muros de cantería adosados a las fábricas preexistentes.
}

con ladrillos. Actualmente el aparejo está parcialmente oculto, ya que al este tiene adosada una vivienda, al norte está parcialmente cubierto por la ladera del cerro y en su fachada sur presenta restos de un revoco con falso despiece de ladrillo dibujado en colores rojo, amarillo y blanco (Fig. 13.1 y 13.2).

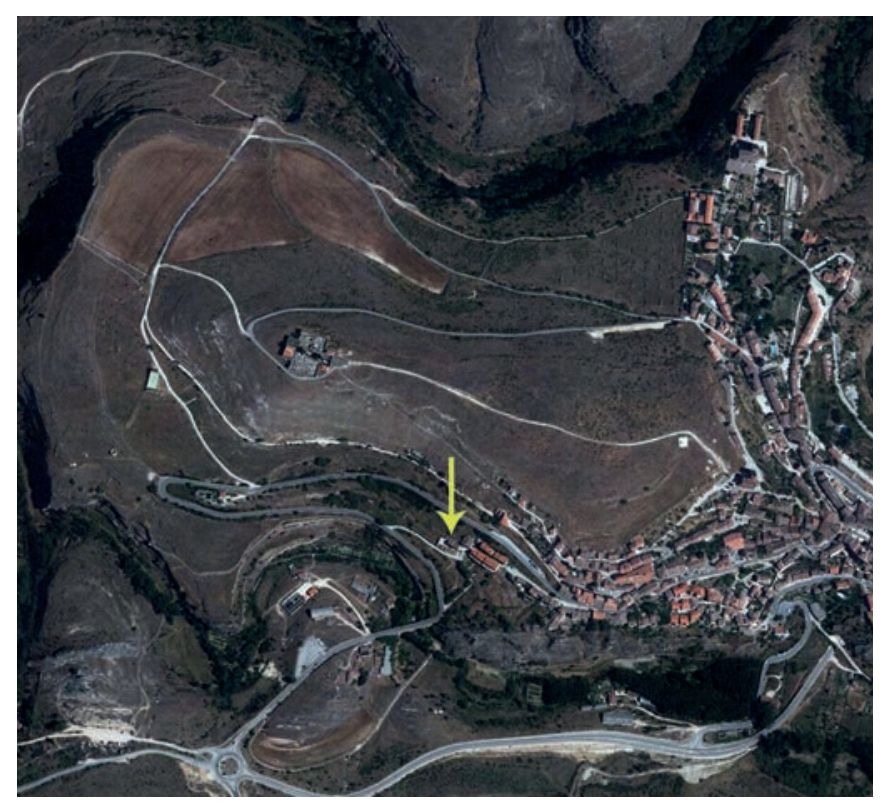

Figura 12. Localización de la Torre de San Andrés de Sepúlveda. Ortofotografía aérea (PNOA-IGN 2015, http://www.ign.es/iberpix2/ visor/).
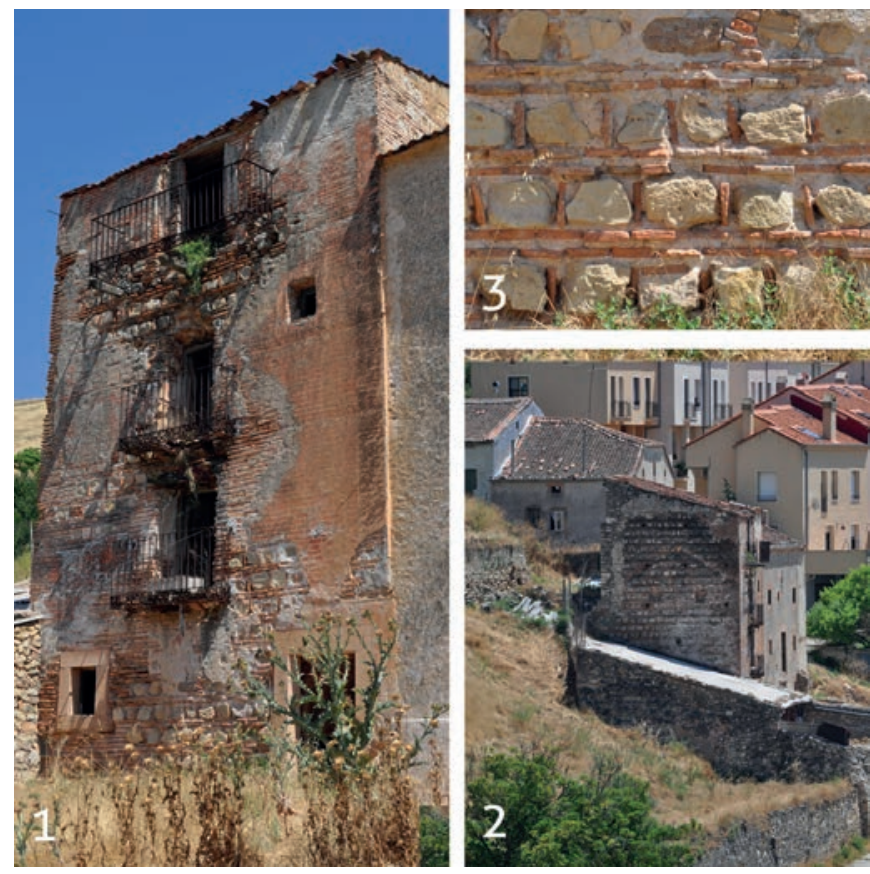

Figura 13. Torre de San Andrés de Sepúlveda: 1) Fachada sur de la torre; 2) Fachada oeste; 3) Detalle del aparejo de la torre en la base de la fachada sur. Fotografías del autor (2013). 
En cuanto al interior, está dividido en cuatro plantas (baja, primera, segunda y tercera), realizadas modernamente con toscos forjados de madera, salvo la segunda, que está cubierta por una bóveda de arista por hojas realizada en ladrillo, de la que hablaremos posteriormente de modo particular. El espacio interior en planta baja es de proporción cuadrangular (4 x $4 \mathrm{~m}$ aproximadamente) y se accede por una puerta moderna abierta en la fachada sur. Cuenta con su acceso original tapiado al oeste, un grueso arco de medio punto en ladrillo solo visible desde el interior, aunque muy transformado. Destacan especialmente tres elementos en este espacio interior. Por un lado, un nicho de planta semicircular y desarrollo semicilíndrico localizado en la fachada este, que está rematado con arco de medio punto de ladrillo y bóveda de cuarto de esfera, elementos visibles solo desde la planta superior, pues el forjado impide su contemplación desde la planta baja. Dentro de este nicho se conservan en mal estado los restos un arco de herradura en ladrillo (quizá asociado a algún tipo de vano o simple decoración), muy afectado por un acceso moderno a la casa colindante (Fig. 14). Y por otro, en el paramento norte, se conserva un hueco perfectamente guarnecido y aparejado con un falso dintel decorativo de ladrillos a sardinel, que enmarca un pequeño pasillo con bóveda de medio punto de ladrillo, que finaliza sin solución de continuidad, pudiendo tratarse de un armario de incierta funcionalidad. Por último, en la fachada sur se conserva a la altura del suelo el resto de un arco de medio punto tapiado, también realizado en ladrillo, incluido dentro de los paramentos modificados para la incorporación de la caja de escalera en fecha incierta.

El acceso a las plantas superiores se puede realizar únicamente a través de una caja de escalera existente en el interior del muro sur. Su acceso en planta baja está desmontado, pero se trataba de un tiro realizado en madera compuesto de dos tramos (uno adosado al muro oeste y otro al sur) excavados en el paramento de ladrillo a tenor de las huellas que permanecen en él. De la primera a la cuarta planta se accede por una escalera practicada en el núcleo del muro desde la esquina sureste hasta el paramento este, que ha afectado, entre otros elementos, a la propia bóveda. Desconocemos si la escalera es original, ya que la importante transformación que ha sufrido a lo largo de su vida, con la apertura de vanos desde la caja de escalera a las diferentes estancias actuales han desvirtuado enormemente el tiro. A tenor de la morfología de la pieza, nos decantamos porque se trata de una escalera original.

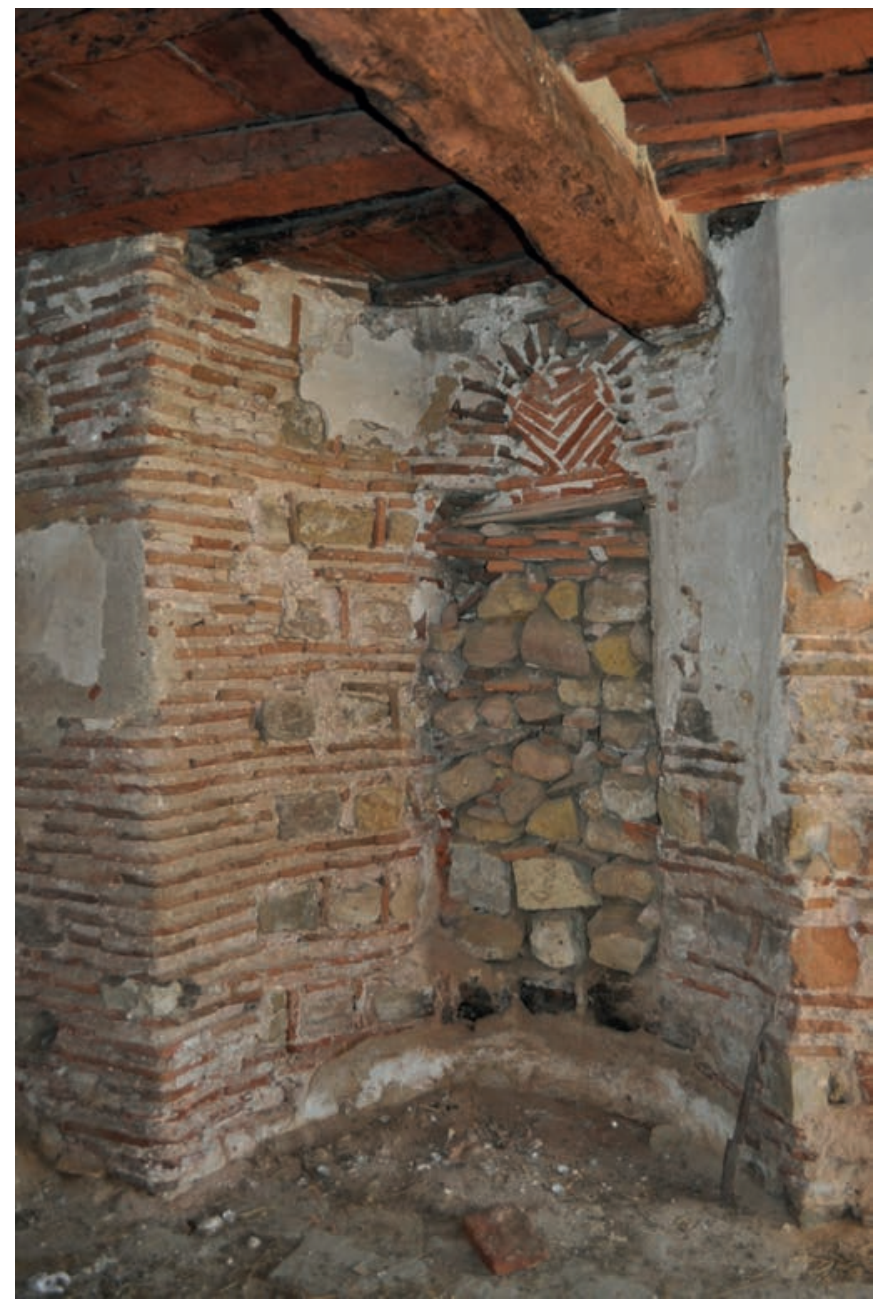

Figura 14. Interior de la Torre de San Andrés, planta baja. Vista del nicho con arco de herradura localizado en la fachada este, interpretado como el mihrab de un oratorio. Fotografía del autor (2013).

En la segunda planta solo se han documentado los restos del arco y la bóveda hemisférica correspondientes al nicho descrito en la planta baja, muy alterado por una puerta que comunicaba con la casa contigua. La estancia de la tercera planta, como ya hemos indicado, se encuentra cubierta por una bóveda de ladrillo. Destacar que se ha documentado un hueco rectangular practicado en el paramento norte, del que llama la atención que esté perfectamente imbricado en las fábricas, por lo que parece original, pudiendo haber servido para el encastre de algún tipo de elemento. La última planta, localizada sobre el extradós de la bóveda, cuenta con unos muros más estrechos que el resto del edificio ( $80 \mathrm{~cm}$ aproximadamente). Este espacio se encuentra muy alterado, puesto que contó con un acceso a la calle por la fachada norte, que todos sus paramentos interiores están reconstruidos con un forro de mampostería concertada trabada con mortero de cal, lo que contrasta con el exterior, donde se ha conservado el aparejo original. 
En cuanto a los materiales de construcción, se han empleado ladrillos nuevos, mampuestos de caliza de procedencia local y fuerte mortero de cal (Fig. 13.3). En el caso de los ladrillos, estos presentan unas medidas homogéneas, siendo similares tanto en paramentos interiores como exteriores, así como la propia bóveda, midiendo aproximadamente $30 / 29 \times 20 / 19 \times 5 / 4 \mathrm{~cm}$. Paralelamente, los tendeles presentan un grosor aproximado de $4 \mathrm{~cm}$, en una proporción 1:1 respecto al del ladrillo, mientras que las llagas están entre 1 y $2 \mathrm{~cm}$, tanto en los paños como las esquinas. A través de las roturas en el muro sur del edificio podemos conocer cómo está construido. Se trata de un muro de doble hoja de mampostería mixta relleno de mortero de cal y trozos de piedra caliza. Cada una de las hojas del muro aparece realizada con el aparejo de mampostería encintada cajeada. Cabe destacar que la homogeneización de hiladas de mampostería que supone la colocación las verdugadas de ladrillo no penetra en el núcleo del muro para unirse con la hoja exterior.

La fachada oeste aparece casi por completo libre de revocos y enlucidos. En ella podemos ver con claridad el aparejo, así como las huellas de diversos elementos. En primer lugar, se conservan todos los mechinales de andamio de su construcción, preparados para que todas las piezas de madera utilizadas fueran recuperables. Se cuidó su colocación a lo largo de la construcción ya que se enmarcaron perfectamente con ladrillos para conformar su forma cuadrangular. Desconocemos si una vez retirado el andamio estos huecos fueron rellenados. También se percibe la huella de la techumbre de una estructura a dos aguas con una anchura mínima superior al propio edificio, localizada a la altura de la tercera planta actual del mismo. Podría tratarse de la huella de la nave de la antigua parroquia de San Andrés, aunque no hay evidencias suficientes que lo prueben.

Se desconoce cómo sería la iluminación del espacio interior, ya que no es posible conocer si alguno de los vanos actuales de la fachada sur supuso agrandar alguno ya existente o no. Actualmente cuentan con sus quicios perfectamente guarnecidos con ladrillo moderno, fruto de la conversión del edificio en vivienda.

En cuanto a paralelos, si bien presenta similitudes con otros edificios en materiales de construcción y en técnicas constructivas, no se han encontrado semejanzas en cuanto a su tipología y funcionalidad. Se han revisado tanto fortificaciones del entorno como fuera del marco de estudio, además de otras tipologías, como torres campanario, tanto del mudéjar toledano (Abad 1991) como de la provincia de Segovia (Ruiz Hernando 1988), sin encontrar parangón. En el caso de los campanarios, por lo general, presentan una caja de escaleras interior, mientras que en San Andrés la escalera se ha embutido en los muros, dejando libre el espacio central (Fig. 16).

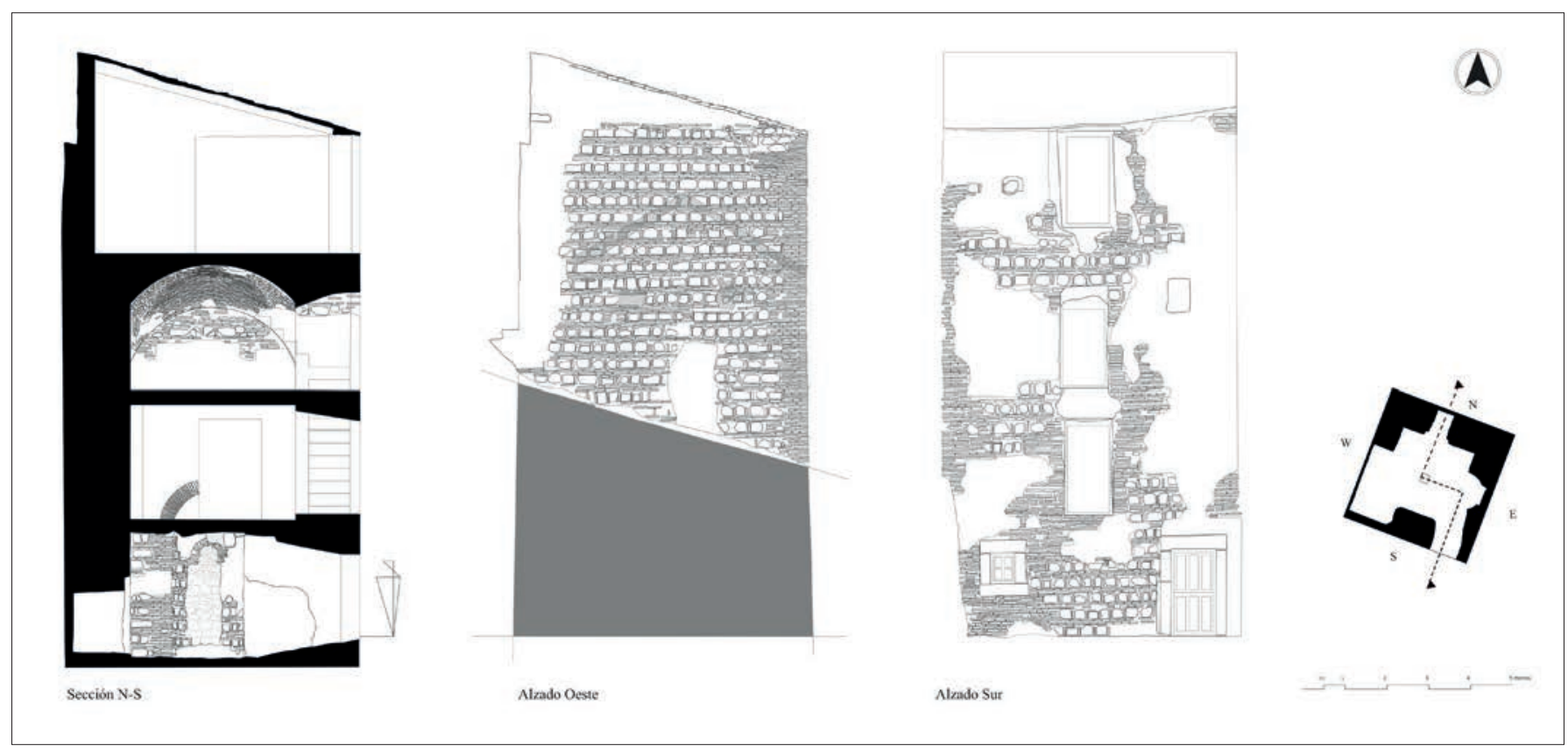

Figura 15. Levantamientos de la Torre de San Andrés: Alzados de las fachadas sur y oeste, y sección N-S. Elaboración propia. 
Aun siendo conscientes de su lejanía, un edificio que presenta ciertas similitudes con San Andrés es la torre Khalef al-Fata de la Kasbah de Susa en Túnez (Fig. 17). Se trata de una almenara o torre de señales marítimas, actualmente faro en uso, localizado en la parte superior de la ciudad, con 22 metros de altura, que cumple una función referencial respecto al puerto, junto con el alminar del ribăt de Susa, en el extremo contrario de la ciudad (AA. VV. 2005: 200-201). Esta torre presenta interiormente una disposición similar a la de San Andrés, al contar con un mihrab orientado en la habitación superior del cuerpo principal de la torre; esta habitación ha sido calificada como oratorio o "mezquitilla". La torre tunecina fue construida entre el 850-860, estando adscrita al periodo aglabí, habiendo sido construida por el maestro de obras Khalaf al-Fata (Lézine 1966; Pavón 1999: 293-296).

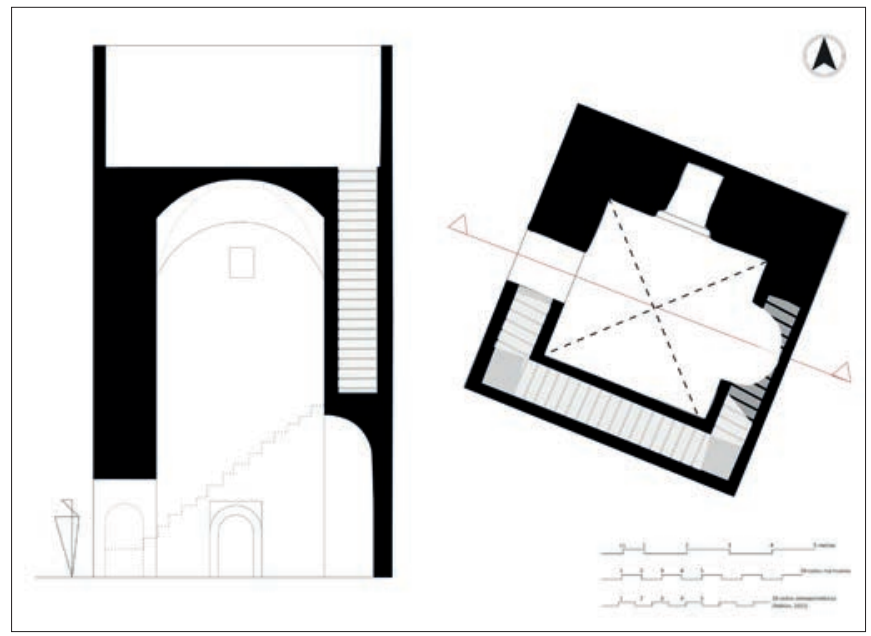

Figura 16. Planta y sección hipotética de la Torre de San Andrés de Sepúlveda. Elaboración propia.

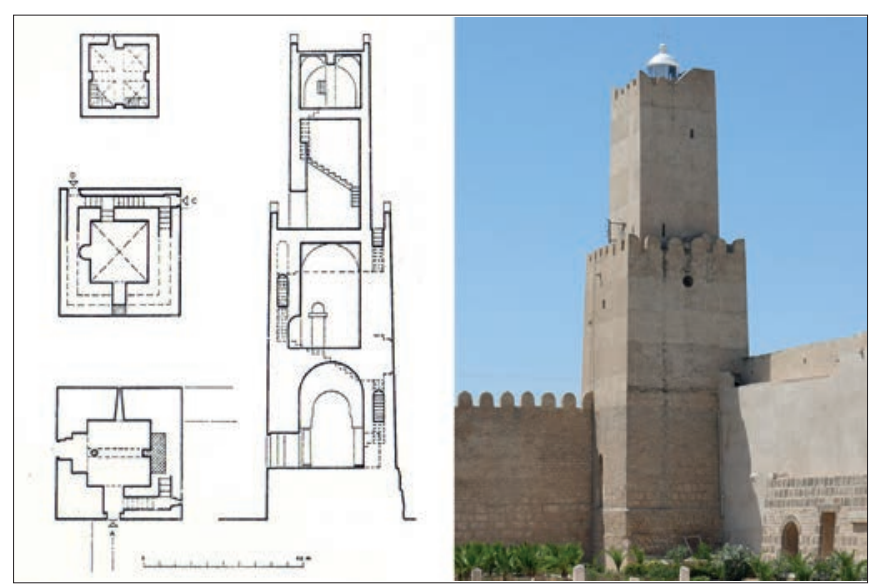

Figura 17. Torre Khalef al-Fata de la Kasbah de Susa (Túnez). Levantamiento (Lézine 1966) y fotografía actual, desde el recinto interior, actual museo arqueológico de Susa (www.flickr.com).
Solo podemos afirmar que, a pesar de las transformaciones posteriores y las adiciones contemporáneas, la torre de San Andrés manifiesta una única fase constructiva original. El espacio interior de la torre está configurado de modo centralizado, cubierto por la bóveda de arista y presidido por un nicho destacado. Presenta ciertas similitudes formales con espacios áulicos andalusíes de los siglos X y XI tipo qubba, reservados para oratorios o mausoleos. El nicho de la planta baja (Fig. 14) podría ser interpretado como un mihrab, que presenta unas proporciones similares a otros conocidos, como el de Almonaster en Huelva (Jiménez 1975), el ribāt de Susa o el de la mezquita de las Tres Puertas de Qayrawán, ambos en Túnez (Creswell 1979; Pavón 2009 y 2010). Por otro lado, la pared en la que se localiza el nicho está orientada $\pm 120^{\circ}$ sudeste (Fig. 15), como la mezquita aljama de Madīnat al-Zahrā', primer edificio andalusí en respetar la orientación canónica de la qībla, finalizada su construcción en 941 (Jiménez 1991: 194).

\section{REFLEXIONES CONSTRUCTIVAS: TÉCNICAS, MATERIALES Y SISTEMAS DEL GRUPO}

Una vez descritos los ejemplos más señeros de este conjunto de edificios, que pretendemos definir como un grupo tecnológico, hemos de poner en relación los resultados, poniendo de relieve tanto las similitudes entre sí como sus diferencias. Podemos definir un aparejo tipo, como aquel que cuenta con todas las características definitorias: dobles verdugadas de ladrillo, tabicas verticales separando cada mampuesto mediante la colocación de un ladrillo a sardinel mostrando el tizón, esquinales de ladrillo, mechinales de fábrica pautados y secuenciados para andamios recuperables $\mathrm{y}$, lo más importante, un ladrillo nuevo de medidas estandarizadas.

En cuanto a las verdugadas dobles de ladrillo, es uno de los elementos que más se repite, ya que solo en algunas torres de flanqueo de la muralla de Buitrago, que todo parece indicar que son producto de una reconstrucción posterior, y en parte de la Torre de la Campana de Cogolludo, que es probablemente de cronología anterior. En cuanto a las tabicas verticales, de nuevo solo en esta torre del castillo de Cogolludo hemos documentado su ausencia casi completa. Por el contrario, los restos localizados en la fachada norte de la iglesia de San Juan Bautista de Talamanca del Jarama solo cuentan con tabicas verticales, sin presentar verdugadas de ladrillo. 
En cuanto a los esquinales documentados, todos están realizados en ladrillo, salvo la ya mencionada torre del castillo de Cogolludo, que presenta esquinales de piedra, realizados con material acarreado de módulo muy dispar. Por último, los mechinales para andamios, perfectamente preparados para recuperar las agujas de madera, solo han sido documentados en aquellos edificios con suficiente entidad como para ser conservados, esto es, en la Torre de San Andrés de Sepúlveda, en la iglesia de San Miguel de Ayllón $\mathrm{y}$ en diferentes lugares de la muralla de Buitrago de Lozoya (Fig. 18, 2 y 3).
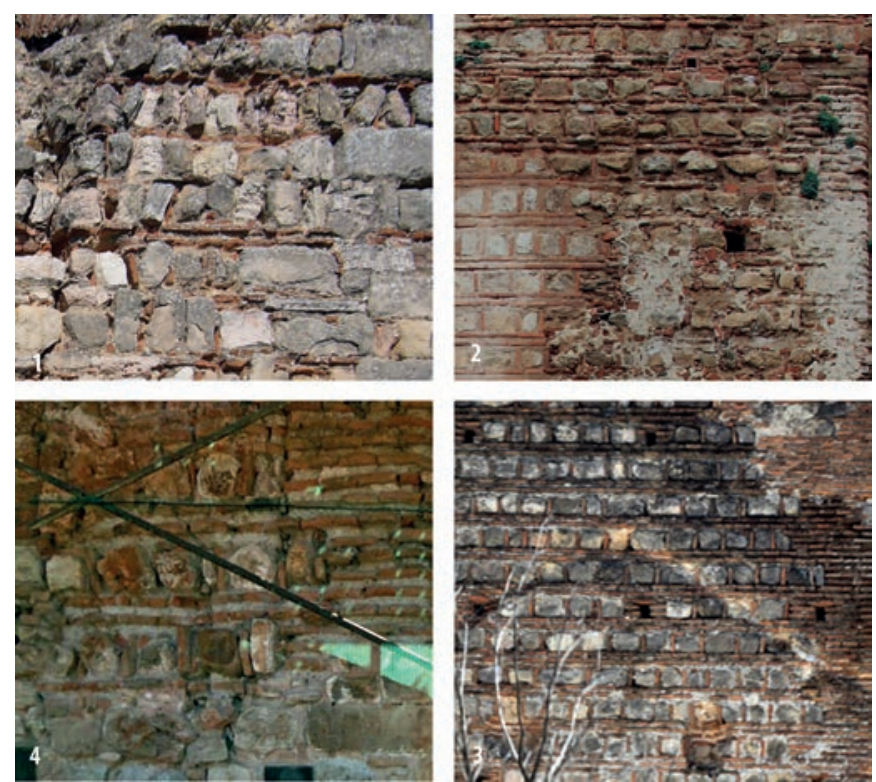

Figura 18. Ejemplos de esquinales en algunos de los edificios mencionados en el texto: 1) Torre de la Campana del castillo de Cogolludo (2007); 2) Fachada intramuros de la Puerta de la Villa de Buitrago (2015); 3) Fachada oeste de la Torre de San Andrés de Sepúlveda (2013); 4) Esquina de la torre sur del Arco de la Villa de Ayllón (2010). Fotografías del autor.

Otro elemento que debemos poner de manifiesto es la íntima relación del aparejo encintado cajeado con obras de tapia de tierra. Podemos ver claramente su asociación en el castillo de Ayllón, donde Zamora ya apuntaba esta relación, incluso si se tratara de un "chapado o forro" de unas estructuras de tapia preexistentes (Zamora 1993: 75, 81 y 122). En cambio, en la muralla de Buitrago, a través del uso de la fotografía histórica podemos observar diferentes relaciones. Por un lado, podemos ver cómo la tapia y el aparejo encintado son utilizados a la vez, uno conformando la hoja exterior de las torres del recinto, y la tierra apisonada macizando el interior de la estructura, como ocurre en la torre 5
(Fig. 19). Del mismo modo, en Buitrago se puede ver cómo torres de mampostería encintada se adosan a la muralla de tapia calicastrada original de la villa, pero no podemos dilucidar si estas torres son un forro de torres anteriores. En el caso de los restos del castillo de Fresno, al no encontrarse exteriormente trasdosados, podríamos aventurar que estuvieran asociados a una estructura perdida realizada en tierra.
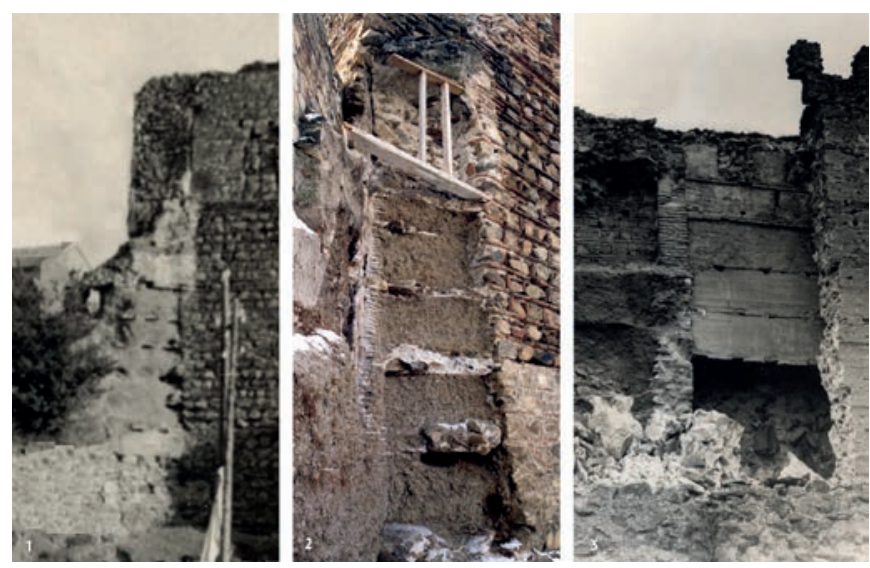

Figura 19. Relaciones de mampostería encintada y tapia de tierra en Buitrago de Lozoya: 1) Desarrollo en altura de la muralla de tapia de tierra calicastrada y reparación del adarve en la torre 1 del recinto amurallado, todo ello amortizado posteriormente al dotar de un adarve corrido a todo el recinto; 2) Detalle de la sección del muro de tierra obtenida durante los trabajos de restauración de mediados de los años 80 donde se aprecian las cuñas de cal de los cajones de tierra, así como tortas de cal en la base de los mismos. Además, muestra la posterioridad del adarve y de la propia torre; 3) Torre 5 de la muralla tras su colapso en los años 50 del siglo XX. Se puede observar que la torre era maciza hasta el cuerpo de guardia, que quedó amortizado en las obras de remodelación de la cerca en la Baja Edad Media. Tanto el cuerpo de guardia como la cara exterior de la torre están realizados en mampostería encintada cajeada, mientras que la torre es de tierra apisonada y forrada de mampostería encintada. La ruina de esta torre también dejó al descubierto la primera muralla del recinto y su remate almenado, realizada con tapia de tierra calicastrada. Fotografías gentileza de Javier Pastor.

En cuanto a las medidas de los ladrillos, la toma de datos métricos realizada ${ }^{9}$ en todos los edificios integrantes del grupo permite observar que todos mantienen un sistema de medidas sin demasiadas variaciones, aunque hay algunas desviaciones. También hay que poner de manifiesto que no se ha documentado una producción modular, esto es, que todos los ladrillos, con sus diferencias, presentan un mismo módulo; no hay ladrillos

\footnotetext{
9 La toma de datos efectuada consistió en medir una discreta muestra de entre 7 y 10 ladrillos de cada edificio del catálogo, ofreciéndose la medida media simple de sus tres dimensiones (Medida 01) en la Tabla 1, así como la medida más discordante de la muestra (Medida 02). Se acompañan otras medidas de ladrillos obtenidas de modo similar por otros autores para otros edificios o parte de ellos a los que no se ha tenido acceso (Medida 03). Esta aproximación no suple en absoluto un estudio pormenorizado de base mensiocronológica que podría corroborar o desmentir algunas de las hipótesis planteadas.
} 
producidos que supongan, por ejemplo, la mitad o el doble de los documentados, como ocurre en las producciones de época romana.

Hay que destacar también que, a la espera de estudios más profundos, parece que se trata de ladrillos que obedecen a un sistema de medición andalusí, muy cercanos a las formas que se pueden ver en Toledo, tanto en época tardocalifal como taifa, además de toda la construcción posterior de tipología mudéjar. Demuestran una cercanía significativa con el codo ma'muniyya de 47,14 $\mathrm{cm}$, vinculado a un pie de $31,43 \mathrm{~cm}^{10}$.

En este sentido podemos proponer que el origen de las cuadrillas de albañiles que construyeron estos edificios en mampostería encintada cajeada pudo estar en Toledo. De hecho, esta mampostería es similar al aparejo "tipo A" definido para Toledo y asociado a los siglos X-XI (Rojas y Villa 1999: 583-588). Se compone de cajones de mampostería de alrededor de $30 \mathrm{~cm}$ de altura enmarcados por verdugadas de ladrillo. La única diferencia estaría en que, en la mayor parte de los casos, carecen del ladrillo a sardinel enmarcando los mampuestos.

El edificio más paradigmático de este momento en Toledo es, sin lugar a dudas, la mezquita de Bab al-Mardum o ermita del Cristo de la Luz. Supone un modelo arquitectónico andalusí del Toledo tardocalifal en torno al año mil y en él se constata la utilización normalizada del ladrillo

10 Un resumen actualizado sobre la tradición metrológica andalusí puede leerse en Jiménez 2015: 3-6. en la ciudad del Tajo a lo largo del siglo X. Este edificio, a juzgar por la fecha de su epígrafe fundacional, realizado en ladrillo, fue construido en el 999. Este hecho es matizable a juzgar por los resultados de la reciente restauración integral, ya que se han obtenido fechas de carbono-14 de la cimentación del edificio, proponiendo un arco de fechas más antiguo que la fecha del epígrafe, un arco entre 690900 cal AD (Ruiz Taboada 2009: 70). Anteriormente, tanto Pavón (2000: 155-187 y 2009) como Villanueva et alii (2000: 1123-1130) se percataron por separado de que este edificio contaba con dos etapas constructivas diferentes, una inicial, en la que se configuró un oratorio de formas sencillas y de planta cuadrangular, y una segunda fase de reforma y engalanamiento promovida por un mecenas que pone su nombre en el epígrafe conservado en la fachada oeste. En esta reforma el edificio pierde nueve sencillas cubiertas y adquiere la cubierta de nueve bóvedas individuales tan excepcional que luce hoy día. Este hecho se puede constatar estratigráficamente, ya que toda la segunda fase se adosa a la primera, hecho notado por los investigadores antes citados. Además, para aquilatar la relación de la mezquita toledana con los constructores de los edificios con ladrillo en los confines de la frontera de al-Ándalus, se ha documentado en las cimentaciones del edificio ciertas hiladas de mampostería encintada que presentan ladrillos a sardinel separando los mampuestos (Ruiz Taboada 2009: 53-71 y 2012: 176-177) (Fig. 20).

Para comprender cómo se pensaron estos edificios y la tradición arquitectónica que hay detrás de su diseño,

\begin{tabular}{|l|c|c|c|}
\hline \multicolumn{1}{|c|}{ EDIFICIO } & MEDIDA 01 & MEDIDA 02 & MEDIDA 03 \\
\hline Ayllon (Castillo) & $30 \times 20 \times 4$ & & $30 \times 25 \times 4$ (Zamora 1993: 75) \\
\hline Ayllón (Puerta del Arco) & $29 \times 19 \times 5$ & & \\
\hline Ayllón (San Miguel) & $28 \times 20 \times 4$ & & $30 \times 20 \times 3-4-5$ (Zamora 1993: 116) \\
\hline Buitrago (Puerta) & $30 \times 19 \times 4$ & & $30 \times 22 \times 4-5$ (Zamora 1993: 113) \\
\hline Buitrago (Torre 1) & & & $33 \times 20 \times 4-5$ (Zamora 1993: 106) \\
\hline Cogolludo & $29 \times 19 \times 4,5$ & $31 \times 22 \times 5,5$ & $36 \times 16 \times 5$ (Zamora 1993: 107) \\
\hline Fresno de Cantespino & $31 \times 20 \times 4$ & & $30 \times 20-22 \times 4-5$ (Zamora 1993: 112) \\
\hline Fuentidueña & $36 \times 22 \times 5,5$ & $34 \times 17 \times 5$ & $30 \times 20 \times 4-5$ (Zamora 1993: 109) \\
\hline Jadraque & $29 \times 19 \times 4,5$ & & $27 \times 17 \times 4$ (Pavón 2000: 167) \\
\hline Peñafora & $28 \times 20 \times 4$ & & $30 \times 20 \times 5$ (Ruiz Taboada 2009: 64; 2012: 191) \\
\hline Sepúlveda (San Andrés) & $30 \times 19 \times 4$ & & $25 \times 18 \times 4$ (Ruiz Taboada 2009: 64; 2012: 191) \\
\hline Talamanca (San Isidro) & $30 \times 20 \times 4,5$ & & $30 \times 20 \times 4,5$ (Pavón 1988: 75) \\
\hline $\begin{array}{l}\text { Toledo (Mezquita Bab al-Mardum, } \\
\text { c. 970 ó 1000) }\end{array}$ & & & \\
\hline $\begin{array}{l}\text { Toledo (Mezquita Bab al-Mardum, } \\
\text { inscripción) }\end{array}$ & & & \\
\hline Toledo (Mezquita de Tornerías) & & & \\
\hline
\end{tabular}

Tabla 1. Mediciones de los ladrillos de los edificios estudiados. Se incluyen las medidas propias (01 y 02) y las tomadas de otros autores (03). 
es conveniente acercarse al sistema de medidas con el que se proyectó cada uno de ellos. Haciendo una primera aproximación metrológica a la lectura de los edificios que integran este grupo, en el caso de la Torre de San Andrés, podemos ver que el espacio exterior del edificio mide aproximadamente $14 \times 14$ codos ma'munies, de 47,14 cm (Hernández 1961-1962: 10; Vallvé 1976: 345). Del mismo modo, el reciente estudio Roldán-Medina (2015) nos ofrece un interesante módulo antropométrico para el codo de $39,59 \mathrm{~cm}$, medida con la que ha estudiado las fábricas emirales y califales de la mezquita de Córdoba. Aplicando este módulo sobre la medida exacta del interior de la torre $(3,95 \mathrm{~m}$ de lado) nos da una medida de $10 \times 10 \operatorname{codos}^{11}$ (Fig. 21).

11 Unas medidas tan redondas nos empujaron a extender estas mediciones a otros edificios estudiados, como la iglesia de San Miguel de Ayllón, la Puerta de Alfonso VIII en Fuentidueña o la Puerta de la Villa de Buitrago. Esta última plantea, en una primera medida, unos resultados muy significativos, como son 20 codos de anchura para la fachada intramuros $(8,2 \mathrm{~m})$. Todas las medidas obtenidas en los edificios anteriores, a la espera de poder realizar un estudio metrológico completo y exhaustivo, son los suficientemente prometedoras para que en el futuro puedan ser consideradas como un indicio sobre la filiación y cronología de estos edificios.
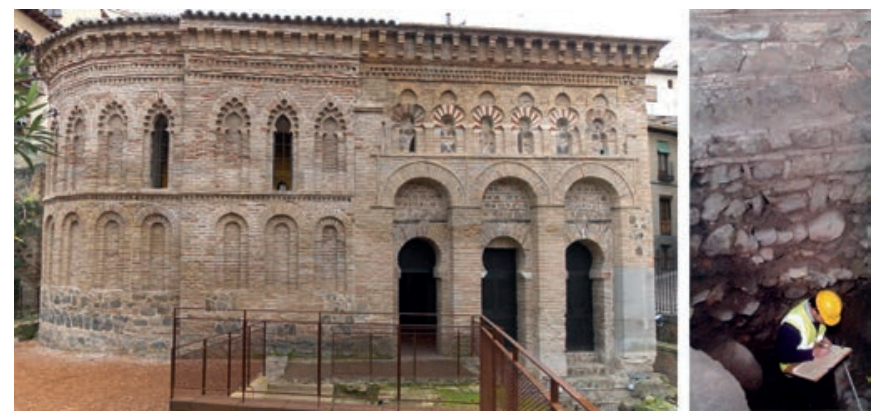

Figura 20. Vista exterior de la fachada norte de la mezquita de Bab alMardum o ermita del Cristo de la Luz de Toledo (Fotografía: Wikimedia commons). A la derecha, detalle de la cimentación del muro este de la mezquita durante los trabajos de excavación arqueológica donde se pueden ver algunos ladrillos a sardinel enmarcando mampuestos (Fotografía: Ruiz Taboada 2009: 64).

En cuanto a sistemas constructivos complejos se refiere, solo podremos acercarnos a la valoración de dos ejemplos, cuyo estudio podría proporcionar elementos de comparación y establecer una propuesta de adscripción cronológica. Por un lado, estaría la bóveda de arista por hojas en ladrillo de San Andrés (Fig. 22.1) y por otro el ejemplo

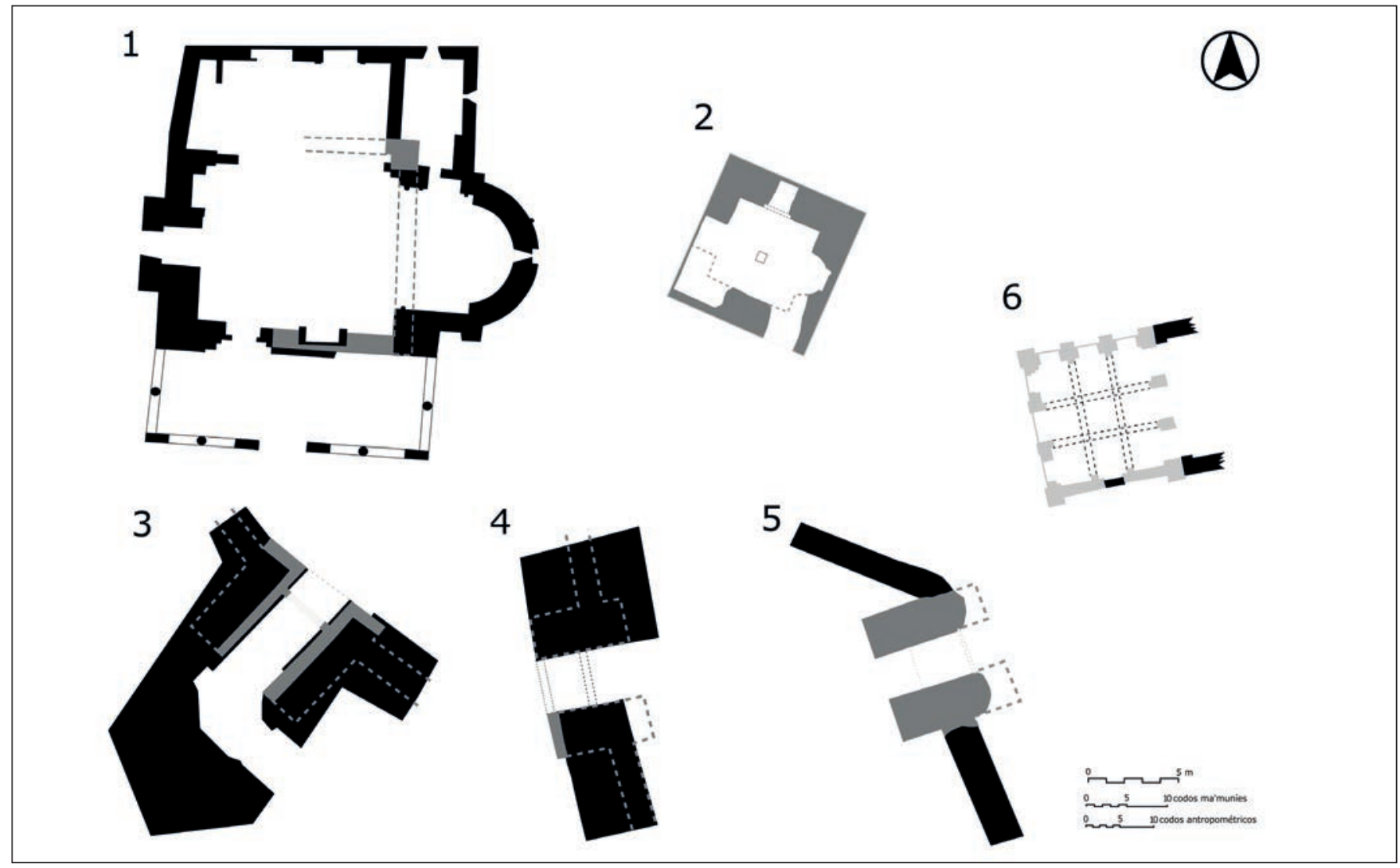

Figura 21. Plantas comparadas de diversos edificios tratados en el texto, señalando en gris sus fases altomedievales y en punteado gris las hipótesis de reconstrucción: 1) iglesia de San Miguel de Ayllón; 2) Torre de San Andrés de Sepúlveda; 3) Puerta de la Villa / Torre del Reloj de Buitrago de Lozoya; 4) Arco de la Villa de Ayllón; 5) Puerta de Alfonso VIII en Fuentidueña. A modo comparativo, se incluye una planta esquemática de la mezquita de Bab al-Mardum (6). Elaboración propia. 

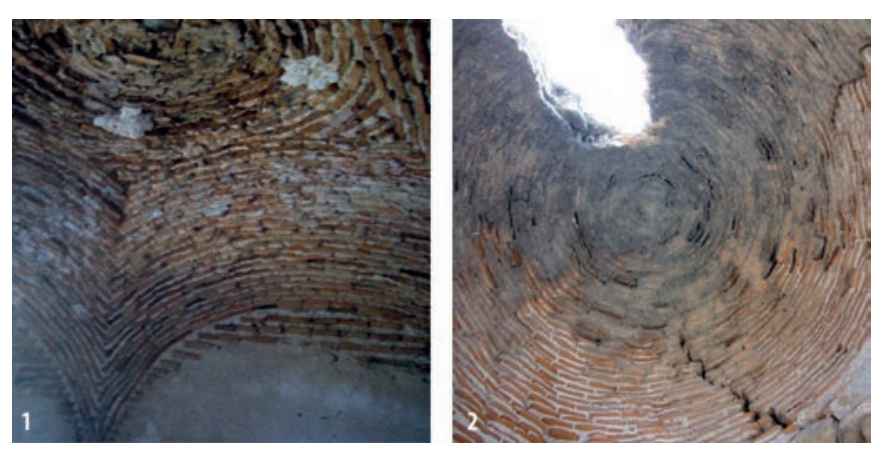

Figura 22. Bóvedas de la zona de estudio: 1) Bóveda de arista construida por hojas de geometría vaída de la Torre de San Andrés (2015); 2) Cúpula de ladrillo de la Torre de la Campana del castillo de Cogolludo (2007). Fotografías del autor.

de la Torre de la Campana del castillo de Cogolludo. Esta última se trata de una cúpula de ladrillo realizada por hiladas horizontales con ladrillo macizo nuevo de medida homogénea que constituye el remate del desarrollo cilíndrico del interior de la torre, mientras que el exterior de la misma es cuadrangular (Fig. 22.2). Inicialmente se planteó que el remate en cúpula se debía a la escasa pericia del constructor (Daza, López-Muñiz y Vela 2013: 633-639), pero posteriormente se ha propuesto que se trate de la cámara superior de un campanario a la que se accedía a través de una escalera de caracol, de ahí la planta circular (Daza 2018: 280).

En cambio, la bóveda de arista por hojas en ladrillo de San Andrés (Fig. 22.1), es muy singular. Aunque es un modelo muy utilizado en la arquitectura toledana, no es común en la provincia de Segovia. Además de en Sepúlveda, solo ha sido documentado en la iglesia parroquial de Santa María del Castillo de Maderuelo formando parte de dos capillas laterales contiguas, ambas de planta cuadrada, cuya adscripción cronología se ha fijado en la Baja Edad Media (Ruiz Hernando 1988: 97$98)^{12}$. En cambio, se trata de una tipología bastante utilizada desde la arquitectura bizantina hasta la arquitectura medieval de la ciudad de Toledo y su entorno, habiendo trascendido incluso a la arquitectura tradicional en Extremadura (Sánchez Leal 2000: 995-1003).

\footnotetext{
12 Este edificio, con un origen románico, presenta una serie de elementos de clara influencia toledana, donde, además de las citadas bóvedas, cuenta con una solución decorativa al lado norte del tramo recto presbiterial de la cabecera. Se trata de una composición de tres arcos de herradura de ladrillo sobre mampostería mixta, que utiliza material constructivo acarreado, y que quiere emular, quizá, la fachada de la mezquita de Bab al-Mardum, en Toledo, presentando una similitud muy significativa con las galerías del claustro mudéjar de la iglesia de San Andrés de Toledo (Delgado 1987b: 121-160). A pesar de que emule este edificio, creemos que se debe a las reformas realizadas en el edificio en la Baja Edad Media, a juzgar por el tamaño de los cajones de mampostería a los que se asocia. Este edificio ha sido interpretado, por esta solución constructiva, como una mezquita edificada en el siglo IX, hipótesis aventurada que no está contrastada (García Izquierdo 2015: 354-357; Lorenzo 2014: 255-258).
}

En el primer caso, se puede documentar con asiduidad en edificios bizantinos de los siglos VI y VII (Mango 1989: 8-10; Krautheimer 2005: 261-268). Se conocen ejemplos de esta bóveda en muchos edificios paradigmáticos, por ejemplo, en la ciudad de Estambul, la antigua Constantinopla. Se pueden ver tanto empleadas en la cubrición de zonas de paso como recurso rápido no lujoso, o como base constructiva para que luego se decore con fresco o mosaico. Destacan los ejemplos del nártex de la basílica de Santa Sofía, donde se combinan bóvedas de arista por hojas y esféricas, así como las bóvedas de la cisterna de Yerebatán, ambos ejemplos datados en época de Justiniano. De hecho, Krautheimer (2005: 267) considera que este tipo de bóvedas ligeras, realizadas con o sin cimbra, suponen una novedad que surge en este momento como sustituto barato y sencillo de las bóvedas hormigonadas, siendo el soporte de múltiples decoraciones. En el caso toledano, podemos encontrar este recurso en las ocho bóvedas perimetrales de la mezquita de Tornerías, antigua mezquita de los moros, cuya construcción ha sido fechada en la segunda mitad del siglo XI, pero se mantuvo en uso como mezquita de mudéjares hasta 1502 (Passini 2004: 150). También encontramos este tipo de bóvedas en la planta baja del palacio de Galiana, almunia construida al este del puente de Alcántara, cuyo origen está atribuido a la iniciativa de Al-Mamún (siglo XI), si bien las estructura conservadas son de construcción posterior. En este sentido, Pavón (1988: 95-96 y 102104), siguiendo a Torres Balbás, prefiere retrasar su cronología a principios del siglo XIII. Existen otros ejemplos en el propio territorio toledano, donde esta bóveda de ladrillo ha sido utilizada para cubrir aljibes en algunas fortificaciones adscritas a los siglos X y XI, el aljibe menor del castillo de Calatalifa, en Villaviciosa de Odón (Pérez Vicente 1990: 141-144). Otros ejemplos, ya más modernos, los encontramos cubriendo las estancias de una de las grandes albarranas del castillo de Montalbán (San Martín de Montalbán, Toledo), cuya cronología propuesta en de los siglos XIIXIII, donde se combinan con otros tipos de bóvedas similares, como de arista y esquifadas. En Guadalajara hay también ejemplos significativos, como la bóveda del cuerpo de campanas de la torre de la iglesia de Santa María de la Fuente (Trallero 2017: 43), o la del torreón de Alvar Fáñez (Pavón 1984: 31-32).

Otro ejemplo, de dudosa adscripción cronológica, es el resto de bóveda de ladrillo que perdura en el único paramento de entidad que resta en pie de la basílica del 
conjunto arqueológico de Carranque (Toledo), asociada a un complejo rústico tipo villae, datado a finales del siglo IV o principios del siglo V (Fernández-Galiano et alii 2001; García-Entero et alii 2014: 477-486). Este ejemplo, similar al documentado en Sepúlveda, ha suscitado ciertas controversias cronológicas, ya que Utrero (2006: 117 y 531-532) rechaza su cronología tardoantigua y propone que sería de cronología plenomedieval, al haber documentado sus excavadores que el edificio amortizó en su construcción estructuras datadas en el siglo IV, por lo que la basílica sería de un momento posterior. De la misma manera, la investigadora manifiesta que el tipo de bóveda que presenta el edificio es un recurso muy utilizado en la construcción toledana de torno al siglo XII, por lo que no sería original, sino producto de la readaptación medieval del edificio como lugar de culto. A nuestro juicio, la modulación de los ladrillos que componen el paramento y la bóveda de Carranque es bastante homogénea, lo que sumado a la conexión estratigráfica que manifiestan, hace que nos decantemos por proponer que se trate de una construcción coetánea.

\section{INTERPRETACIÓN Y PROPUESTA CRONOLÓGICA PARA ESTE GRUPO TECNOLÓGICO}

Una vez descritos los diversos ejemplos y contextualizados los diferentes materiales, técnicas y sistemas constructivos, tras la reflexión realizada, creemos estar en posición de asegurar que todos estos edificios se realizan en un momento concreto, un espacio de tiempo no muy dilatado y por unas mismas manos. Creemos que estos edificios podrían datarse a finales del siglo $\mathrm{X}$, construidos tras la toma de Sepúlveda por Almanzor en el 984, en el contexto de las múltiples campañas que realiza en ese momento sobre este sector de los extrema durii. En este sentido, los postulados de Zamora para esta mampostería (Martín, Tardío y Zamora 1990; Zamora 1993, 1998, 2008 y 2011; Zamora y Vela 2005) podrían confirmarse, así como las propuestas concretas para la Torre de San Andrés (Conte y Fernández 1993). Pero habría que razonar la presencia de estos edificios, e intentar dilucidar a qué iniciativa obedecen y si, como decíamos en la introducción, pueden ser la manifestación material de una colonización andalusí en toda regla, donde se construyeron tanto fortificaciones como otros edificios de corte no defensivo (ya sea religioso o habitacional). La Torre de San Andrés, a la luz de su singularidad, puede ser interpretada como un edificio religioso construido por albañiles acostumbrados a la obra fortificada. Quizá se trate de un oratorio relacionado con el ejercicio del ribāt o con una almenara, construido tras la toma de Almanzor de 984. Del mismo modo, los restos de la iglesia de San Miguel de Ayllón podrían estar en relación con un edificio de culto, descartando sus funciones defensivas. Recordemos que las zonas de frontera habían sido testimonio de la presencia de murābițūn que colaboraban en las tareas de defender los territorios del islam, y que plazas como Gormaz, Talavera o Madrid fueron lugares a los que se retiraron musulmanes devotos a hacer ribät, y llegado el caso, a emprender el yihād (Echevarría 2003: 73; Marín 1993: 129 y 2004: 199).

El proceso histórico en el que se enmarcaría esta colonización que proponemos está íntimamente relacionado con el avance castellano hacia el Sistema Central a mediados del siglo $\mathrm{X}$, y la inicial consolidación de Sepúlveda como puntal logístico en torno a 940. Este hecho causó una reacción en el Estado andalusí, cristalizando mediante la intensificación de las expediciones durante el gobierno de Almanzor. Debido a la cada vez más preocupante presencia castellana al sur del Duero, puso su punto de mira en esta zona como objetivo de sus primeras expediciones veraniegas. A partir de este momento se sucedió un incesante trasiego de tropas por la zona durante los últimos años del siglo X que tuvieron por objeto las tierras inmediatas al norte del Sistema Central, ya como objetivo final o intermedio de las expediciones. Las primeras aceifas de Almanzor se realizaron conjuntamente con su suegro Gālib, el general de origen eslavo que gobernó la Marca Media en delegación de Al-Hakam II y, tras la muerte de este en el 976, del joven califa Hishâm II. De estas primeras campañas destaca la realizada conjuntamente por los dos generales contra Sepúlveda en 979 (séptima campaña), en la que no se consiguió conquistar la plaza, aunque toda la tierra circundante fue arrasada (Dikr 1983: 197; Castellanos 2002: 190). A lo largo de la década de los 80 , una vez finalizado el enfrentamiento con Gālib que culmina con la muerte de este, las tropas califales vuelven a moverse con naturalidad por todo el norte peninsular, asaltando León, Santiago y Salamanca, entre otras plazas. Respecto a nuestra zona de estudio, en el 983 Almanzor eligió la zona de Sacramenia como objetivo de su vigésima campaña, en la que ajustició a todos los hombres y llevó consigo como esclavos al resto de la población (Martínez Díez 2005: 507). Y en el 984, en su vigésimo 


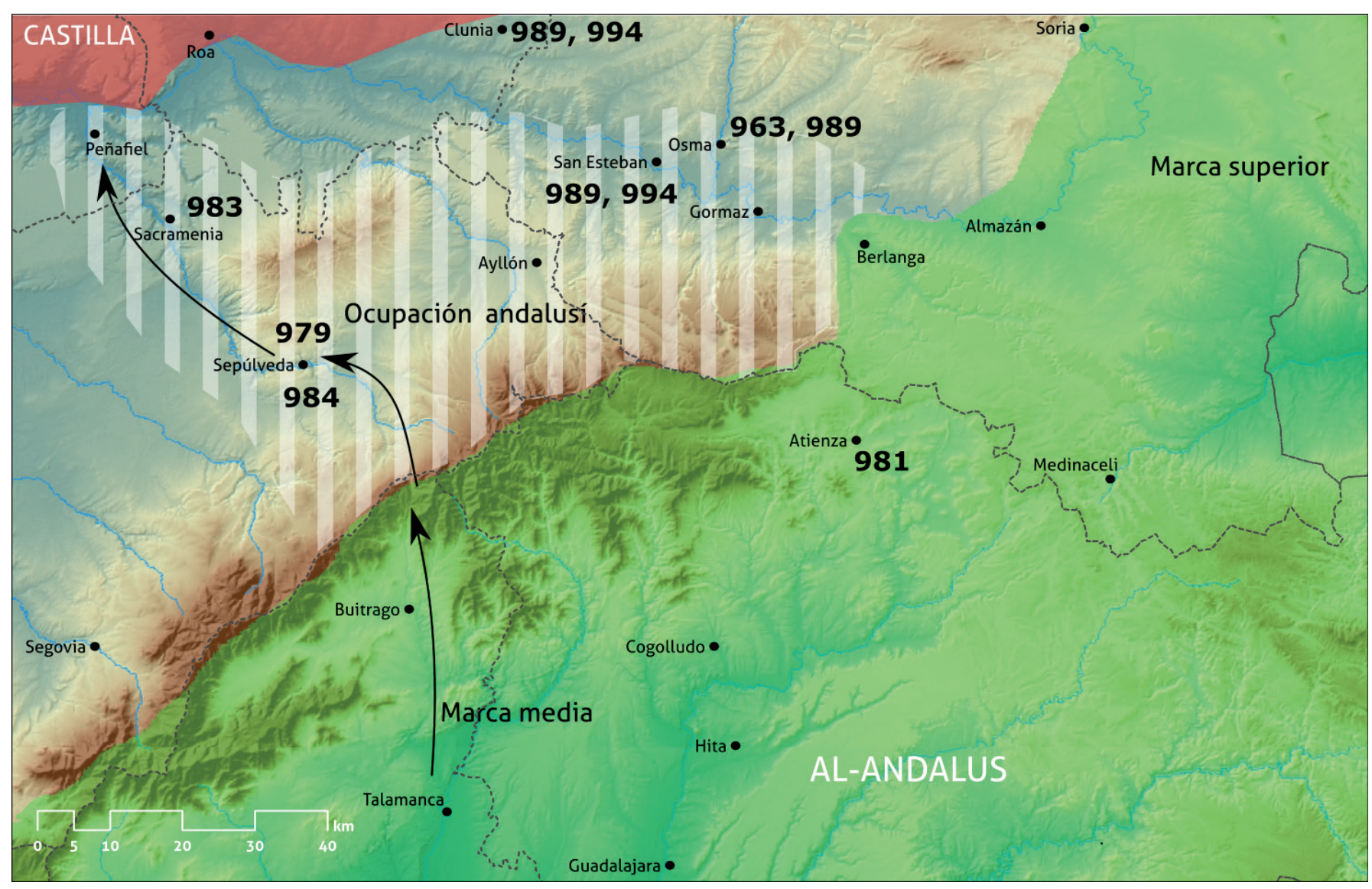

Figura 23. Mapa de las campañas de Almanzor en las últimas décadas del siglo X en torno a Sepúlveda y el valle del río Duratón. Estas campañas supusieron no solo la ocupación militar y la consolidación de la frontera, sino también una colonización de la margen sur del Duero a tenor de la hipótesis propuesta tras el estudio de los restos documentados. Se indican las fechas de asedio y conquista de diferentes plazas (Daza 2015: fig. 7).

segunda campaña, asaltó y destruyó Sepúlveda, para lo cual "instaló los almajaneques y la combatió día y noche hasta conquistarla por las armas. Obtuvo botín y cautivos en número incontable y la destruyó" (Dikr 1983: 198). La conquista de Sepúlveda supuso un punto de inflexión en su política expansiva, ya que eliminaba la presencia más meridional de los castellanos en la Extremadura. La consecuencia no tardó en llegar, un año después, en el 985, el monarca Ramiro III de León y sus condes fueron obligados a someterse a la tutela y protección cordobesa, lo que supuso el establecimiento de una guarnición andalusí en León, que permaneció allí hasta el 987. Tras este episodio se sucedieron diversas revueltas que fueron represaliadas con dureza por las tropas amiríes, asaltando, entre otras, las plazas de Salamanca, Alba de Tormes y Condeixa. También la ciudad de Coímbra fue atacada, pero su caso hay que singularizarlo respecto de los otros, puesto que, a diferencia de anteriores algaradas, se tiene documentado que en ella se llevó a cabo una repoblación con musulmanes, que se mantuvo hasta 1064 (Martínez Díez 2005: 514). Sepúlveda y el valle del Duratón no volverán a aparecer mencionados entre las plazas asaltadas por los cordobeses.

Durante el gobierno de Almanzor, uno de los pilares fundamentales de su legitimación como hââyib y de la consolidación de su poder sobre el califa fue siempre una gran labor propagandística, que enaltecía su papel como implacable defensor de la fe. Entre las manifestaciones públicas más notorias, además de las propias algazúas, cabe destacar la gran ampliación de la mezquita de Córdoba, realizada en el escaso lapso de tiempo, entre 987 y 990, y otras obras pías y gestos piadosos que le granjearon un gran apoyo popular (Echevarría 2011: 208). En este contexto de fervor religioso llegó incluso al extremo de prohibir el ejercicio e investigación de ciertas ciencias, o a realizar expurgos en las bibliotecas califales, destruyendo libros considerados heréticos.

Otro punto a destacar dentro de la política legitimista de Almanzor es la teoría que plantea una probable actividad repobladora al norte del Sistema Central en las 
zonas conquistadas, como la documentada en Coímbra. El efecto propagandístico de estas posibles colonizaciones no tendría límites, pues haber extendido las fronteras de al-Ándalus también suponía un logro proselitista para el aumento de la fe y de las tierras del Islam. De hecho, se atribuyeron unas palabras a Almanzor en su lecho de muerte, recogidas al inicio de este trabajo: "Cuando conquisté las tierras de los cristianos y sus fortalezas las repoblé [y avituallé] con los medios de subsistencia de cada lugar y las sujeté con ellas hasta que resultaron favorables completamente" (Ibn al-Kardabūs 1993: 86). En opinión de Maíllo Salgado (1984: 165), “[...] se nos presenta, más que como caudillo guerrero, como organizador del territorio musulmán, al promover una política de asentamientos dentro del territorio enemigo: repoblado tierras, ciudades y fortalezas con gentes musulmanas, y proveyéndose de lo necesario con los recursos que le ofrecía el propio país conquistado". Esta actitud, también atribuida por Ibn Idarī a 'Abd al-Malik, hijo de Almanzor, es interpretada por Maíllo Salgado como el indicio documental de que las reorganizaciones del territorio conquistado fueron efectivas a través de un sistema de colonización de tipo militar " [...] que permitía, además de poner en marcha la economía de una determinada comarca, la autosuficiencia en caso necesario, el desarrollo de las comunicaciones y la eficacia de los ejércitos musulmanes en caso de ataque o de contraataque, fomentando así un campesinado militarizado y paliando, por este medio, la escasez de hombres y soldados en regiones desangradas por las luchas fronterizas" (Maí1lo Salgado 1984: 166-167). Este sistema sería parecido, según Maíllo Salgado, al de las themas bizantinas ${ }^{13}$.

Por todo ello, durante el gobierno de Almanzor, como parte de la estrategia propagandística de su poder, pudo potenciarse la presencia y apoyo del ribāt como un modo de propiciar una colonización de tierra ocupada. Podría ser de esperar que la sierra norte de Madrid y Guadalajara, en los confines de al-Ándalus, o el valle

\footnotetext{
13 Se trata de un sistema de demarcaciones fronterizas militarizadas a partir del establecimiento de campesinos-soldados (stratiotes) bajo el mando de un stratego utilizada por el Imperio bizantino a partir del gobierno de los emperadores Mauricio (582-602) y Heraclio (610-641), suponiendo una ampliación del sistema de exarcados establecidos durante la etapa justinianea. Las themas generaron un campesinado libre que atendía su propia parcela de tierra a la vez que defendían la frontera en tiempo de conflicto. Este sistema tuvo una implantación progresiva a lo largo de los siglos VII a X a lo largo de todo el Imperio, comenzando en las provincias periféricas hasta que se instalan en la península de Anatolia. Fueron en ocasiones foco de revueltas, ya que los strategoi acumularon un gran poder y se postularon en diferentes ocasiones con alternativas propias a la sucesión del trono bizantino. Este sistema pudo ser adoptado por los Abbasíes desde mediados del siglo VIII para la defensa de sus fronteras (Maíllo 1984: 166, n. 5).
}

del Duratón, un espacio más allá de los límites del califato y con un pasado eremítico atestiguado, fueran el asentamiento de estos personajes que en su ejercicio del $\hat{y} i h \bar{a} d$, aunaran la ascesis con la defensa de la frontera. En el caso de San Andrés, podría ser que la torre jugara algún tipo de papel como lugar central de referencia, o se tratara del mausoleo de alguno de estos muȳâhidīn anónimos, como el caso del asceta de origen toledano Sulayman Ibn Ibrahim al-Qaysi, que se asentó en el castillo de Gormaz para defender la frontera del islam y su tumba, años después de su muerte, fue visitada incluso por los cristianos (Marín 2004: 194).

\section{CONCLUSIONES}

Tras la descripción y contextualización realizada se puede afirmar que los vestigios de mampostería encintada cajeada, ya en edificios completos o en reparaciones de otros existentes, son las evidencias materiales de una colonización andalusí al norte del Sistema Central oriental. Este proceso obedece a la iniciativa estatal, que tanto reparó fortificaciones cercanas a la frontera dentro de al-Ándalus, para fortalecer los caminos y pasos al norte, como edificó edificios nuevos, ya militares o religiosos. No se trataría de la primera colonización efectuada de este modo: hacia 946, con el traslado de la capital de la Frontera Media a Medinaceli, se produce otro proceso similar, si bien materialmente es más heterogéneo (Daza 2015: 236-240).

Como se ha visto, estas nuevas construcciones demuestran una gran homogeneidad constructiva ofrecida por la incorporación del ladrillo y de las técnicas de albañilería que no tienen precedentes inmediatos en la zona estudiada. Los edificios de mampostería encintada cajeada son los únicos que se construyen utilizando ladri1lo en ese momento en este espacio y están ejecutados en un corto lapso de tiempo. Pero la presencia califal en los territorios del Duero oriental no posibilitó la consolidación de estas técnicas, debido fundamentalmente a que se trataba de albañiles foráneos (procedentes probablemente de Córdoba y Toledo) que viajaron con las tropas y retornan a su origen tras la finalización de sus labores. Una vez que este grupo de edificios se finaliza, la producción de ladrillo se detiene durante un gran espacio de tiempo. La incorporación del ladrillo nuevo como producto industrial estandarizado llegará con el Románico a partir de la segunda mitad del siglo XII (Araguas 2003 y 2005; Ruiz Hernando 1988; Valdés 1984), y no se incorporará a las construcciones militares hasta el siglo XIII. 
El origen de las cuadrillas de albañiles que construyeron estos edificios pudo estar en Toledo. Ante la necesidad estatal de realizar reformas en ciertas fortalezas y edificar edificios destinados a las nuevas poblaciones, se pudieron encargar estos trabajos a alarifes que habitaran en la misma zona de implantación o en la más próxima, a fin de que se movieran junto a las tropas para realizar sus trabajos. Esta hipótesis estaría apoyada en el tipo de ladrillo empleado, responde a los módulos conocidos en el Toledo tardocalifal-taifa, donde la mezquita de Bab alMardum o del Cristo de la Luz ejerce un papel de modelo arquitectónico (Rojas y Villa 1999: 583-588; Ruiz Taboada 2009: 55-70). La evolución constructiva del edificio pone de manifiesto la utilización normalizada del ladrillo en Toledo a lo largo del siglo X, por lo que puede ser el punto de origen de los alarifes que venimos comentando. Estas cuadrillas de constructores no solo conocían el paso final de su ciclo productivo (su puesta en obra y aparejo) sino que, al moverse con las tropas por la frontera lejos de casa, implantaron todo el ciclo allá donde se requirieran sus servicios: realizaron la captación de las arcillas y su procesado, así como la construcción de hornos efímeros orientados a cocer todo el material latericio. El mismo proceso se realizaba para la obtención de las cales para el mortero. Estas labores de creación de una industria ladrillera, aunque efímera, implicarían la intervención de un grupo significativo de personas profesional y coordinado para desarrollar toda la producción y posterior edificación.

En resumen, podemos decir que los aparejos encintados en nuestro marco de estudio son totalmente homogéneos, salvo escasas excepciones que se han visto anteriormente. Sobre este modelo hemos podido ver algunas variantes, como las documentadas en las torres de flanqueo de Buitrago, cuyo aparejo utiliza una única verdugada en vez de dos; o también el aparejo de la Torre de la Campana del castillo de Cogolludo, más cercano a un aparejo atizonado que emplea ladrillo (y ocasionalmente tejas recicladas) para homogeneizar las hiladas de material acarreado mal graduado. También se ha documentado como variante dudosa los restos en la fachada norte de la iglesia de San Juan Bautista de Talamanca del Jarama.

Este estudio solo se queda en una propuesta. El estudio del ciclo productivo del ladrillo en este contexto ha de avanzar desarrollando proyectos de investigación entre diferentes equipos y profesionales que colaboren para poder establecer un verdadero corpus mensiocronológico de los usos del ladrillo. También será necesario profundizar en la contextualización estratigráfica de todos los ejemplos ya que, por el momento, no contamos con ninguna excavación o no se han publicado las que si se han efectuado.

\section{AGRADECIMIENTOS}

Quiero agradecer muy significativamente el apoyo de diversas personas: en primer lugar, a los profesores Félix Lasheras y a Fernando Vela, directores de mi tesis doctoral; a Alonso Zamora, por su tiempo y generosidad; a los propietarios de la Torre de San Andrés de Sepúlveda y a Diego Conte por la oportunidad que me brindaron para poder acceder a los pisos superiores de la torre en junio de 2015; a Javier Pastor, por proporcionarme las fotografías antiguas de Buitrago de Lozoya que publicó en su libro sobre la muralla de la villa (2008); a Amador Valdés López, propietario del castillo de Cogolludo por su apoyo en los estudios realizados en el inmueble; y a Miguel Ángel G. Valero y Elena Vega, por la información y fotografías proporcionadas de su excavación en la calle San Isidro de Talamanca del Jarama.

\section{FUENTES}

Dikr = Anónimo. 1983: Una descripción anónima de al-Andalus [Dikr bilad al-Andalus]. L. Molina (ed. y trad. con introducción, notas e índices, 2 tomos). CSIC / Instituto Miguel Asín, Madrid.

Ibn al-Kardabūs. 1993: Historia de Al-Andalus. F. Maíllo Salgado (ed.). Akal, Madrid.

Ibn Hayyān. 1973: Al-Muqtabis II-I. M. A. Makkī (ed.). Beirut.

\section{BIBLIOGRAFÍA}

AA. VV. 1993: Castillos, Fortificaciones y Recintos Amurallados de la Comunidad de Madrid. Comunidad de Madrid, Madrid.

AA. VV. 2005: Ifriqiya: Trece siglos de arte y arquitectura en Túnez. Electa, Madrid.

AA. VV. 2006: Enciclopedia del Románico en Castilla y León: Segovia. Fundación Santa María La Real - Centro de Estudios del Románico, Aguilar de Campoo.

Abad Castro, C. 1991: Arquitectura mudéjar religiosa en el arzobispado de Toledo. Caja de Ahorro, Obra Social Cultural, Toledo.

Alba Calzado, M. 2003: "Apuntes sobre la cerámica de época tardoantigua (visigoda) y altomedieval (emiral) en Extremadura, a partir del registro arqueológico emeritense", en L. Caballero Zoreda y L. Mateos Cruz (coords.), Repertorio de arquitectura cristiana en Extremadura: época tardoantigua y altomedieval, pp. 293-332. Instituto de Arqueología de Mérida / CSIC, Mérida.

Araguas, P. 2003: Brique en Architecture dans l'Espagne médiévale (XIIème XVème siècle). Casa de Velázquez, Madrid.

Araguas, P. 2005: "Maçonneries murales de brique dans l'Espagne médiévale", Arqueología de la Arquitectura, 4, pp. 161-168.

Azuar Ruiz, R. 2005: "Las técnicas constructivas en la formación de alAndalus", Arqueología de la arquitectura, 4, pp. 149-160. 
Bermejo Crespo, J. L. y Muñoz López-Astilleros, K. 1994: "Una explotación agrícola en el territorio de los Banū Sālim: excavaciones en 'Vereda de Sedano' o 'Las Fuentecillas' (San Fernando de Henares, Madrid)”, Boletín de Arqueología Medieval, 8, pp. 205-225.

Bonet Correa, A. 1987: Historia de las artes aplicadas e industriales en España. Ediciones Cátedra, Madrid.

Caballero Zoreda, L. y Rodríguez Trobajo, E. 2010: Las iglesias asturianas de Pravia y Tuñón: arqueología de la arquitectura, Anejos de Archivo Español de Arqueología 54. CSIC, Mérida.

Caballero Zoreda, L. y Utrero Agudo, M. a Á. 2005: "Una aproximación a las técnicas constructivas de la Alta Edad Media en la península Ibérica. Entre visigodos y omeyas", Arqueología de la Arquitectura, 4, 169-192.

Caballero Zoreda, L. y Utrero Agudo, M. ${ }^{a}$ Á. 2013: "El ciclo constructivo de la alta Edad Media hispánica. Siglos VIII-X”, Archeologia dell'architettura, 18, pp. 127-146.

Cánovas Guillén, P. 2005: El material cerámico de construcción de la Antigüedad y la Alta Edad Media: la basílica del Tolmo de Minateda, Serie I. Estudios. Número 155. Instituto de Estudios Albacetenses, Albacete.

Castellanos Gómez, J. 2002: Geoestrategia en la España musulmana: las campañas militares de Almanzor. Ministerio de Defensa, Madrid.

Catalán Ramos, R. y Rojas Rodríguez-Malo, J. M. 2009: “La necrópolis de Boadilla: aspectos funerarios y contexto cronocultural de un asentamiento de época visigoda", en J. Pinar Gil y T. Juárez Villena (eds.), Contextos funeraris a la Mediterrània nord-occidental, Mesa Redonda. San Cugát del Vallès (octubre 2009), Gausac 34-35, pp. 223-236.

Cobos, F., Retuerce, M. y Hervás, M. A. 2001: "Esquema del dominio político del Duero Superior en la Edad Media”, V Congreso de Arqueología Medieval Española (Valladolid, marzo de 1999), vol. II, pp. 759-773. Junta de Castilla y León / Asociación de Arqueología Medieval Española, Valladolid.

Cómez Ramos, R. 2001: Los constructores en la España medieval. Universidad de Sevilla, Sevilla.

Conte Bragado, D. y Fernández Bernaldo de Quirós, I. 1993: Introducción a la arqueología en el Cañón del Duratón. Diputación Provincial, Segovia.

Crego Gómez, M. 2007: Toledo en época omeya (ss. VIII-X). Diputación Provincial, Toledo.

Creswell, K. A. C. 1979: Compendio de arquitectura paleoislámica. Universidad de Sevilla, Sevilla.

Daza Pardo, E. 2001: "El Castillo del Cid (Jadraque)", Castillos de España, 120, pp. 51-55.

Daza Pardo, E. 2005: "Los castillos de Jadraque. Evolución constructiva del castillo del Cid durante la Edad Media”, en A. Ruibal Rodríguez (coord.), Actas del II Congreso de Castellología Ibérica (Alcalá de la Selva, Teruel, 8-11 noviembre 2001), pp. 801-818. AEAC / Diputación de Teruel, Guadalajara.

Daza Pardo, E. 2015: Técnicas y materiales de la construcción fortificada altomedieval en el centro de la Península Ibérica: métodos de análisis a través de la arqueología y la historia de la construcción. Tesis doctoral inédita. E. T. S. Arquitectura (UPM) [en línea] http://oa.upm.es/40100/.

Daza Pardo, E. 2018: “Arqueología y construcción histórica del castillo de Cogolludo (Guadalajara). Forma y contextos entre el medievo y la modernidad", en M. A. Cuadrado Prieto, (coord.), Boletín de la Asociación de Amigos del Museo de Guadalajara. Arqueología en Guadalajara. Trabajos inéditos, 8, pp. 257-286.

Daza Pardo, E., López-Muñiz Moragas, G. y Vela Cossío, F. 2013: "Nuevas aportaciones al estudio del castillo de Cogolludo (Guadalajara)", en I. Fernandes (coord.), Fortificações e Território na Península Ibérica e no Magreb - Séculos VI a XVI, pp. 633-639. Edições Colibri - Campo Arqueológico de Mértola, Lisboa.

Delgado Valero, C. 1987a: Toledo Islámico: ciudad, arte e historia. Editorial Zocodover, Toledo.

Delgado Valero, C. 1987b: "El claustro de la iglesia de San Andrés de Toledo. Análisis de una estructura mudéjar", Carpetania, Revista del Museo de Santa Cruz de Toledo, recopilado en (2001): Arte hispano-musulmán (artículos): homenaje a Clara Delgado Valero, pp. 121-160.

Durán Cabello, R. 1999: "El uso del ladrillo en la arquitectura de Augusta Emerita”, en M. Bendala Galán, Ch. Rico y L. Roldán Gómez (eds.), El ladrillo y sus derivados en la época romana, Monografías de Arquitectura Romana 4, pp. 205-220. Universidad Autónoma de Madrid / Casa de Velázquez, Madrid.

Echevarria Arsuaga, A. 2003: "La transformación del espacio islámico (siglos XI-XIII)", en P. Henriet (ed.), Actas del Coloquio Représentations de l'espace et du temps dans l'Espagne des IXe-XIIIe siècles, pp. 34-51. Presses de l'École Normale Supérieure de Lyon, Lyon.

Echevarría Arsuaga, A. 2011: Almanzor: un califa en la sombra. Sílex Ediciones, Madrid.

Fernández-Galiano, D., Piraccini, Ch., Miranda, J. L. y Luna, I. de. 2001: "La más antigua basílica cristiana de Hispania”, en D. Fernández-Galiano (coord), Carranque: centro de Hispania romana (Museo Arqueológico Regional, Alcalá de Henares, 27 de abril a 23 de septiembre de 2001), pp. 69-80.

García Izquierdo, I. 2015: Territorio y poder en la Extremadura castellana. El valle del Riaza, siglos VIII-XII. Tesis doctoral inédita. Universidad de Burgos.

García-Entero, V., Fernández Ochoa, C., Peña Cervantes, Y. y Zarco Martínez, E. 2014: "La evolución arquitectónica del edificio palacial de Carranque (Toledo, España). Primeros avances", en C. Sfameni y P. Pensabene, La villa restaurata e $i$ nuovi studi sull'edilizia residenziale tardoantica, Atti del convegno internazionale del Centro Interuniversitario di Studi sull'Edilizia abitativa tardoantica nel Mediterraneo, CISEM, Piazza Armerina 7-10 novembre 2012, pp. 477-486. Edipuglia, Bari.

Gutiérrez Lloret, S. y Cánovas Guillén, P. 2009: "Construyendo el siglo VII: arquitecturas y sistemas constructivos en el Tolmo de Minateda", en L. Caballero Zoreda, P. Mateos Cruz y M. á. Utrero Agudo (eds.), El siglo VII frente al siglo VII. Arquitectura, Anejos de AEspA, XLVIII, pp. 91-131.

Hernández Jiménez, F. 1961-1962: "El codo en la historiografía árabe de la Mezquita Mayor de Córdoba: contribución al estudio del monumento", $\mathrm{Al}$ Mulk, Anuario de Estudios Arabistas (Suplemento del Boletín de la Real Academia de Córdoba), 2, pp. 5-52.

Jiménez Esteban, J. 1992: Castillos de Guadalajara I. Libros Penthalon, Madrid.

Jiménez Esteban, J. 2005: "Las murallas y el castillo de Ayllón (Segovia)", en A. Ruibal Rodríguez (coord.), Actas del III Congreso de Castellología Ibérica (28 de octubre - 1 de noviembre de 2005, Guadalajara), pp. $633-$ 640. AEAC / Diputación de Guadalajara, Guadalajara.

Jiménez Hernández, A. 2015: "La metrología histórica como herramienta para la Arqueología de la Arquitectura. La experiencia en los Reales A1cázares de Sevilla", Arqueología de la Arquitectura, 12: e022. https://doi. org/10.3989/arq.arqt.2015.001

Jiménez Martín, A. 1975: La mezquita de Almonaster. Instituto de Estudios Onubenses "Padre Marchena" / Diputación de Huelva, Huelva.

Jiménez Martín, A. 1991: "La qibla extraviada", Cuadernos de Madinat alZahra, 3, pp. 189-209.

Juan Ares, J. de. y Cáceres Gutiérrez, Y. 2010: “De Toletum a Tulaytula: Una aproximación al uso del espacio y a los materiales del periodo islámico en el yacimiento de Vega Baja (Toledo)", en AA. VV., Espacios Urbanos en el occidente mediterráneo (s. VI-VIII), pp. 91-99. Toledo.

Juan Tovar, L. C. 2016: "Talleres y hornos cerámicos tardoantiguos y altomedievales en el noroeste peninsular: estruc-turas y tecnología”, en A. Vigil-Escalera Guirado y J. A. Quirós Castillo (eds.), La cerámica de la Alta Edad Media en el cuadrante Noroeste de la Península Ibérica (siglos $V$-X d.C.). Sistemas de producción, mecanismos de distribución y patrones de consumo, Documentos de Arqueología Medieval 9, pp. 339-362. Universidad del País Vasco, Bilbao.

Krautheimer, R. 2005 [1965]: Arquitectura paleocristiana y bizantina. Cátedra, Madrid.

Lacarra, J. M. 1959: "Panorama de la historia urbana en la Península ibérica desde los siglos V al X”, en AA. VV., La Citta nell'Alto Medioevo, Settimane di Studio di Spoleto (10-16 de abril de 1958), VI, pp. 319-355. Centro italiano di studi sull'alto Medioevo, Spoleto.

Lézine, A. 1966: Architecture d'Ifriqiya. Recherches sur les monuments aghlabides. C. Klincksieck, Paris.

López-Muñiz Moragas, G. 2003: El castillo de Jadraque. Aache editores, Guadalajara. 
Lorenzo Jiménez, J. 2014: "El Islam en el valle del Ebro: implantación y visibilidad", Tauste en su Historia, Actas de las XIV jornadas sobre la historia de Tauste, 11 - 15 de febrero de 2013, pp. 229-258. Asociación Cultural "El Patiaz"/ Institución Fernando el Católico, Zaragoza.

Maíllo Salgado, F. 1984: “Algunas noticias y reflexiones sobre la 'Historia de Al-Andalus' de Ibn al-Kardabus”, Studia Historica - Historia Medieval, 2, pp. 163-172.

Maldonado Ramos, L. y Vela Cossío, F. 1998: De arquitectura y arqueología. Munilla-Lería, Madrid.

Mango, C. 1989 [1980]: Arquitectura bizantina. Colección "Historia Universal de la Arquitectura". Aguilar, Madrid.

Manzano Moreno, E. 1991: La frontera de Al-Andalus en época de los Omeyas. CSIC, Madrid.

Marín, M. 1993: "El ribat en Al-Andalus y el Norte de Africa”, en M. Epalza Ferrer (coord.), La Ràpita islàmica: historia institucional i altres estudis regionals, pp. 121-130. San Carles de la Ràpita, Institut d'Estudis Rapitencs, Madrid.

Marín, M. 2004: "La práctica del ribat en al-Andalus (ss. III-V/IX-XI)", en R. Azuar Ruiz (ed.), El ribat califal. Excavaciones e investigaciones (1984-1992), Collection de la Casa de Velázquez 85, pp. 191-201. Casa de Velázquez/Museo Arqueológico de Alicante, Madrid.

Martín Aymerich, M. D., Tardío Dovao, T. y Zamora Canellada, A. 1990: Las murallas de Sepúlveda, (Segovia): un ensayo de aproximación con métodos arqueológicos, a un ejemplo de pervivencia histórica. Diputación Provincial, Segovia.

Martínez Díez, G. 2005: El condado de Castilla (711-1038): la historia frente a la leyenda. Marcial Pons, Madrid.

Mazzoli-Guintard, Ch. 2011: Madrid, pequeña ciudad de Al-Andalus [ss. $[X$-XXI]. Amudayna, Madrid.

Passini, J. 2004: Casas y casas principales urbanas: El espacio domestico de Toledo a fines de la Edad Media. Universidad de Castilla-La Mancha, Toledo.

Pastor Muñoz, F. J. 2008: Una villa medieval fortificada a los pies de la sierra madrileña: restauración del recinto amurallado de Buitrago del Lozoya, Monografías de Patrimonio Histórico 6. Dirección General de Patrimonio Histórico, Madrid.

Pavón Maldonado, B. 1984: Guadalajara medieval. Arte y arqueología árabe y mudéjar. CSIC, Madrid.

Pavón Maldonado, B. 1988: Arte toledano: islámico y mudéjar. Instituto Hispano-Árabe de Cultura, Madrid.

Pavón Maldonado, B. 1999: Tratado de arquitectura hispanomusulmana, II. Ciudades y fortalezas. CSIC, Madrid.

Pavón Maldonado, B. 2000: "El Cristo de la Luz de Toledo. Dos supuestas mezquitas en una", Al-Qantara, XXI, pp.155-184.

Pavón Maldonado, B. 2009: Tratado de arquitectura hispanomusulmana, IV. Mezquitas. CSIC, Madrid.

Pavón Maldonado, B. 2010: "Las mezquitas del Cristo de la Luz de Toledo y de las Tres Puertas de Qayrawan. Arquitectura y decoración”, [en línea] www.basiliopavonmaldonado.es [consultado: 01/2015].

Pérez Vicente, D. 1990: "Excavaciones arqueológicas en Calatalifa”, Madrid del siglo IX al XI, pp. 141-144.

Porter, A. K. 1917: Lombard Architecture. Yale University Press, New Haven.

Prieto Vázquez, G. y Retuerce Velasco, M. 2008: Informe de las excavaciones arqueológicas en el Castillo de Jadraque (Guadalajara). NRT Arqueólogos. Informe inédito.

Quirós Castillo, J. A. 1998: "La sillería y las técnicas constructivas medievales: historia social y técnica de la producción arquitectónica", Archeologia Medievale, XXV, pp. 235-246.

Retuerce Velasco, M. 1983: Castillos de Castilla-La Mancha. Biblioteca Popular, Toledo.

Rodriguez Neila, J. F. 1988: "Perfil histórico de Córdoba en la época visigoda", Boletín de la Real Academia de Córdoba, 114, pp. 127-139.

Rojas Rodríguez-Malo, J. M. y Villa González, R. 1999: "Origen y evolución del aparejo segoviano entre los siglos X y XVI", en P. Bueno Ramírez y R. de Balbín Behrmann (coords.), Actas de II Congreso de Arqueología Peninsular (Zamora, del 24 al 27 de septiembre de 1996), vol. IV (Arqueología romana y medieval), pp. 583-588. Fundación Afonso Henriques, Zamora.
Roldán-Medina, F. J. 2015: “Análisis antropométrico de la mezquita-catedral de Córdoba", Informes de la Construcción, 67 (539), e093.

Ruiz Hernando, J. A. 1988: La Arquitectura de ladrillo en la provincia de Segovia, siglos XII y XIII. Diputación Provincial, Segovia

Ruiz Taboada, A. 2009: "La mezquita en la ermita del Cristo de la Luz y Virgen de la Luz", en S. Sánchez-Chiquito de La Rosa (coord.), Mezquitas en Toledo, a la luz de los nuevos descubrimientos. Los Monográficos del Consorcio 5, pp. 53-71. Consorcio de la Ciudad de Toledo, Toledo.

Ruiz Taboada, A. 2012: Arquitectura residencial y religiosa: Toledo (siglos X a XVIII). La Ergástula, Madrid.

Sainz Esteban, A. 2017: Las murallas en las Comunidades de Villa y Tierra de la Diócesis de Segovia en los siglos XI a XIII. Técnica y sistemas constructivos de la arquitectura defensiva medieval. Tesis doctoral inédita. E. T. S. Arquitectura (UVA).

Sánchez Leal, J. 2000: "Bóvedas extremeñas y alentejanas de rosca y sin cimbra”, en A. Graciani, S. Huerta, E. Rabasa y M. Á. Tabales, Actas del Tercer Congreso Nacional de Historia de la Construcción, pp. 995-1003. I. Juan de Herrera, SEdHC, U. Sevilla, Junta Andalucía, COAAT Granada, CEHOPU, Madrid.

Serrano Santos, N. y Tremiño León, S. 1989: "La Torre de La Martina (Ayllón, Segovia)", en Actas del III Congreso de Arqueología Medieval Española (Oviedo, 27 de marzo - 1 de abril 1989), vol. 2, pp. 341-348. AEAM, Oviedo.

Torres Balbas, L. 1949: Arte Almohade. Arte nazarí. Arte Mudéjar. Ars Hispaniae, Historia Universal del Arte Hispánico, vol. IV. Ed. Plus-Ultra, Madrid.

Torres Balbás, L. 1960: "Talamanca y la ruta olvidada del Jarama", Boletín de la Real Academia de la Historia, CXLVI, pp. 235-266.

Trallero Sanz, A. M. 2017: Mudéjar, pervivencia del mudéjar y neomudéjar en la arquitectura de la ciudad de Guadalajara. Diputación Provincial / Aache Ediciones, Guadalajara.

Utrero Agudo, M. ${ }^{\text {a }}$ A. 2006: Iglesias tardoantiguas y altomedievales en la Península Ibérica: análisis arqueológico y sistemas de abovedamiento. CSIC, Madrid.

Valdés Fernández, M. 1984: Arquitectura Mudéjar en León y Castilla. Universidad de León, León.

Vallvé, J. 1976: "Notas de metrología hispano-árabe. El codo en la España musulmana", Al-Andalus, XLI, 2, pp. 339-354.

Vigil-Escalera Guirado, A. 2003: "Arquitectura de tierra, piedra y madera en Madrid (ss. V-IX d. C.). Variables materiales, consideraciones sociales", Arqueología de la Arquitectura, 2, pp. 287-291.

Vigil-Escalera Guirado, A. 2007: "Granjas y aldeas altomedievales al Norte de Toledo (450-800 d. C.)", Archivo Español de Arqueología, 80, pp. 239-284.

Vigil-Escalera Guirado, A. 2012: “Apuntes sobre la arquitectura de los hogares y hornos domésticos altomedievales del centro de la Península Ibérica (siglos V-VIII d. C.)", Arqueología de la Arquitectura, 9, pp. 167-182.

Villanueva Domínguez, L., Mora Alonso-Moñuyerro, S., Cámara Eguinoa, M. V., Bustamante Montaro, R. y Barahona Rodríguez, C. 2000: "Análisis constructivo de las fábricas del Cristo de La Luz (Toledo)", en A. Graciani, S. Huerta, E. Rabasa y M. Á. Tabales, Actas del Tercer Congreso Nacional de Historia de la Construcción, pp. 1123-1130. I. Juan de Herrera, SEdHC, U. Sevilla, Junta Andalucía, COAAT Granada, CEHOPU, Madrid.

Zamora Canellada, A. 1993: "El castillo de Ayllón (Segovia): Estudio arqueológico e histórico", Estudios Segovianos, 90, pp. 5-522.

Zamora Canellada, A. 1998: "Un particular sistema de construcción militar en los albores del s. XI", en A. Ruibal Rodríguez (coord.), Actas del I Congreso de Castellología Ibérica (Aguilar de Campoo, 14 a 17 de septiembre de 1994), pp. 761-781. Diputación Provincial y AEAC, Palencia.

Zamora Canellada, A. 2011: "Los muros de Sepúlveda. Algunos datos en torno a una revisión”, en M. González Cristobal, G. Herrero Gómez y J. A. Linage Conde (coords.), Sepúlveda en la historia, pp. 151-190. Ayuntamiento y Diputación Provincial de Segovia, Sepúlveda.

Zamora Canellada, A. y Vela Cossío, F. 2005: "Paramentos de fortificaciones en la Segovia prerrománica (siglos VII al XI)", en S. Huerta (coord.), Actas del Cuarto Congreso Nacional de Historia de la Construcción, vol. II, pp. 1137-1154. I. Juan de Herrera, SEdHC, Arquitectos de Cádiz, COAAT Cádiz, Madrid. 